\title{
QL
}

426

J3H67K

1910

MOLL

3) 2 \% 24

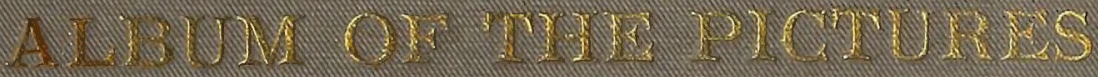

IN COMMTMOSAMON OH:

TIE CONOHOLOONCAR FXHITION

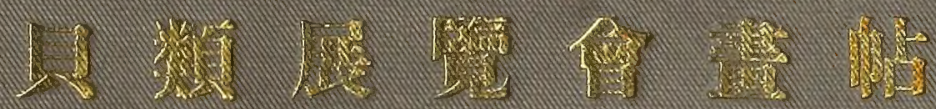

$$
\begin{aligned}
& \text { Y, H R S S } \\
& 3.040 \text {. } \\
& \text { 2.. }
\end{aligned}
$$

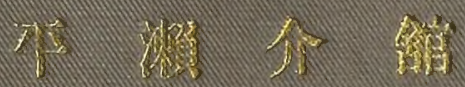

$$
\begin{aligned}
& 1910
\end{aligned}
$$

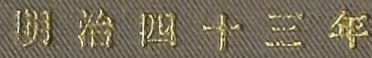

(3) ( in 


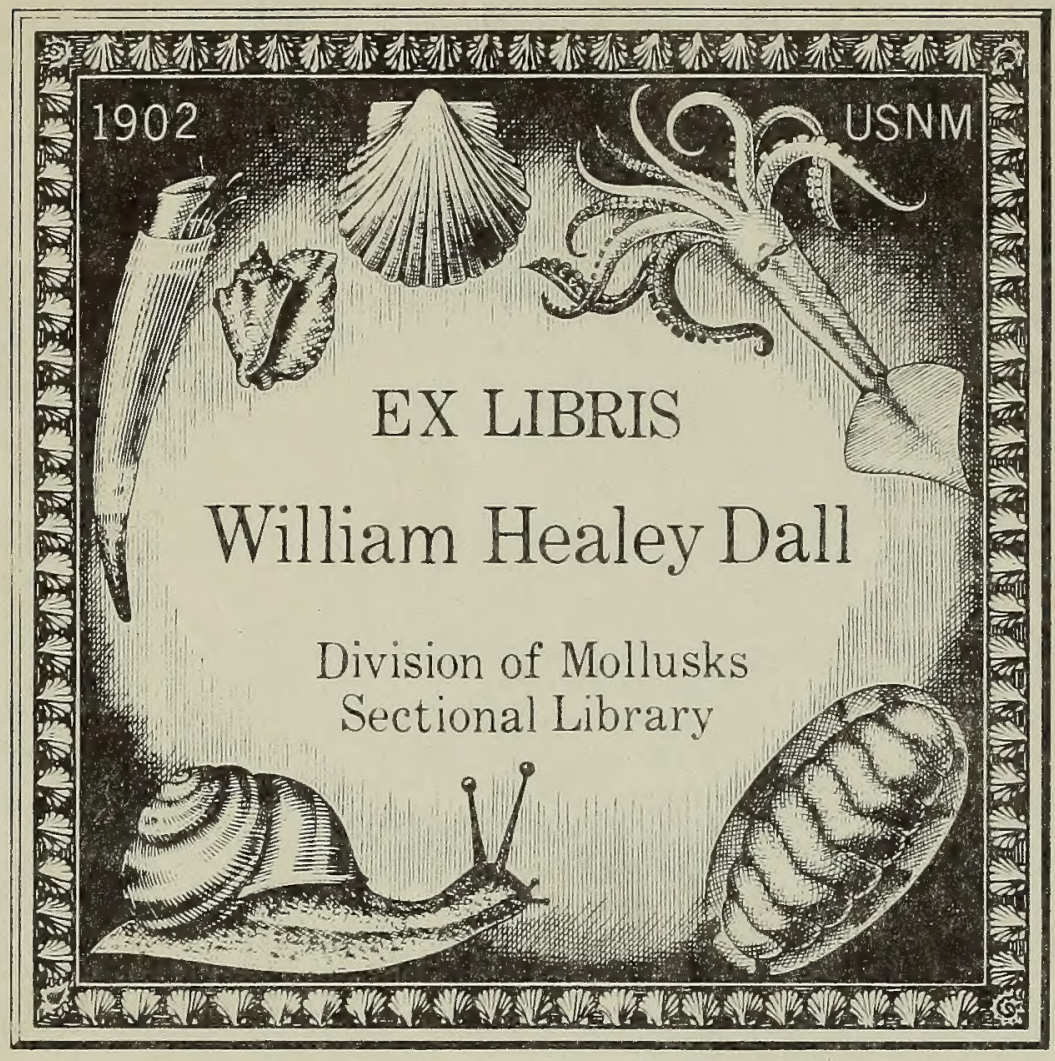




\section{ALBUM OF THE PICTURES}

IN COMMEMORATION OF

\section{THE CONCHOLOGICAL EXHIBITION}

貝類 展覽會 畫帖
Y. HIRASE.
K Y O T O.
京 都

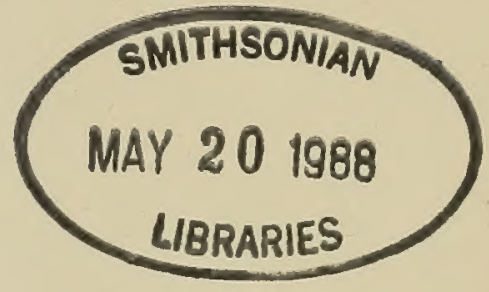

平瀨介 舘

1910

明治四十三年

（非賣品） 


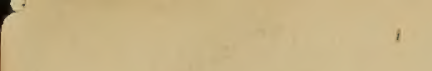




\section{PREFACE.}

Int?

R above twenty years I have devoted myself to the study and collecting of shells.

Now my collection contains about ten thousand species. Of this number, not less than one thousand have been discovered by myself, and added for the first time to the list of shells of the world.

For the benefit of the public, I intended to establish a conchological museum, and show these large numbers of shells to the people.

As a harbinger, a conchological exhibition for a short period was proposed, to which Baron Dr. D. Kikuchi, President of the Kyoto Imperial University, Hon. S. OMORI, Governor of Kyoto Prefecture, and Hon. K. SAIGo, Mayor of Kyoto City, all gave their hearty approval. So it was at last decided to hold the exhibition in a part of the Kyoto Library from Oct 22nd to Nov. 4th, i9lo, lasting two weeks. Great numbers of specimens were sent or presented to the exhibition from conchologists, collectors, and businessmen, both abroad and at home. The number of spectators reached as many as fifteen thousand during the period.
緒匐

予は、具類の探集と研究とに從事 するてと二十餘年、所藏の標本凡飞 壹萬種斗、其內余の新發見にかりる 者殆んど千種に達しれれば、余は之 を公䍃の観覽に供せんが爲めに、貝 類博物舘を剑設せんと欲し、其先駱 として、少地京都帝國大學總長、大 森京都府知事、西的京都市長等の賛 助を得、京都圖書舘に於て明治四十 三年十月云二日よb十一月四日迄具 類展覽會を開設せしが、内外の學者 實業家等の出品寄贈頗る多く、觀客 の数亦一萬五千人に達せb。 
Now I shall briefly describe the exhibition rooms.

In the north room, Japanese specimens were arranged according to the latest classification. In the south room, foreign specimens were exhibited in the order of the nations a tourist passes when he goes round the world. In the hall connecting the two rooms, large specimens both from home and abroad were shown. On the walls of every room and the hall, various pictures, paintings, and illustrations were hung. In many other places I exhibited all kinds of articles that were made of shells or in the shape of shells, various designs and many books or pamphlets relating to shells, and great numbers of other specimens.

In this way, I tried my best to break the monotony of the exhibition, and to give pleasure and satisfaction to all visitors, both scholars and businessmen, high and low, and young and old. An account of it appeared in several newspapers. I am well convinced that this exhibition has more or less effected its purpose in diffusing the knowledge of shells, and an interest in them among people who were all strangers to nature.

In memory of the exhibition, I have had photographs taken of the most important and prominent specimens, mod ls and other things, and have made an album of them, so that I can present a copy to each of my dear, kind friends.

Y. HIRASE.
先づ其陣列の楿垐を記さんに、北 室には最近の分類に徐つて、日本產 の標本を配列し、南室には國别とし て、世界一周の順序に、外國產標本 を榢列し雨室を連始る長さ廊下には 內外產の大形標本を出陳し、壁上に は圖畫、說明等を揭げ、所々に百般 の利用品、應用品、圖案、書籍、其 他諸栝の參考品走鍇綜し、以て範圍 嫰主諸展覽會の單調を破り、學者、 實業家、婦女老幼をして其目を娱む しめんと兔めんり、諸新聞は其狀况 走報し、多少具類に關する智識と趣 些とを普及しれるもの】如し、故に 余は圭要子る陳列品の第真を一朋に 集めて、之を同好の士に頒ら、之を 永久に紀念とするてと、みしね。

平 瀨 與 一 郎 記 


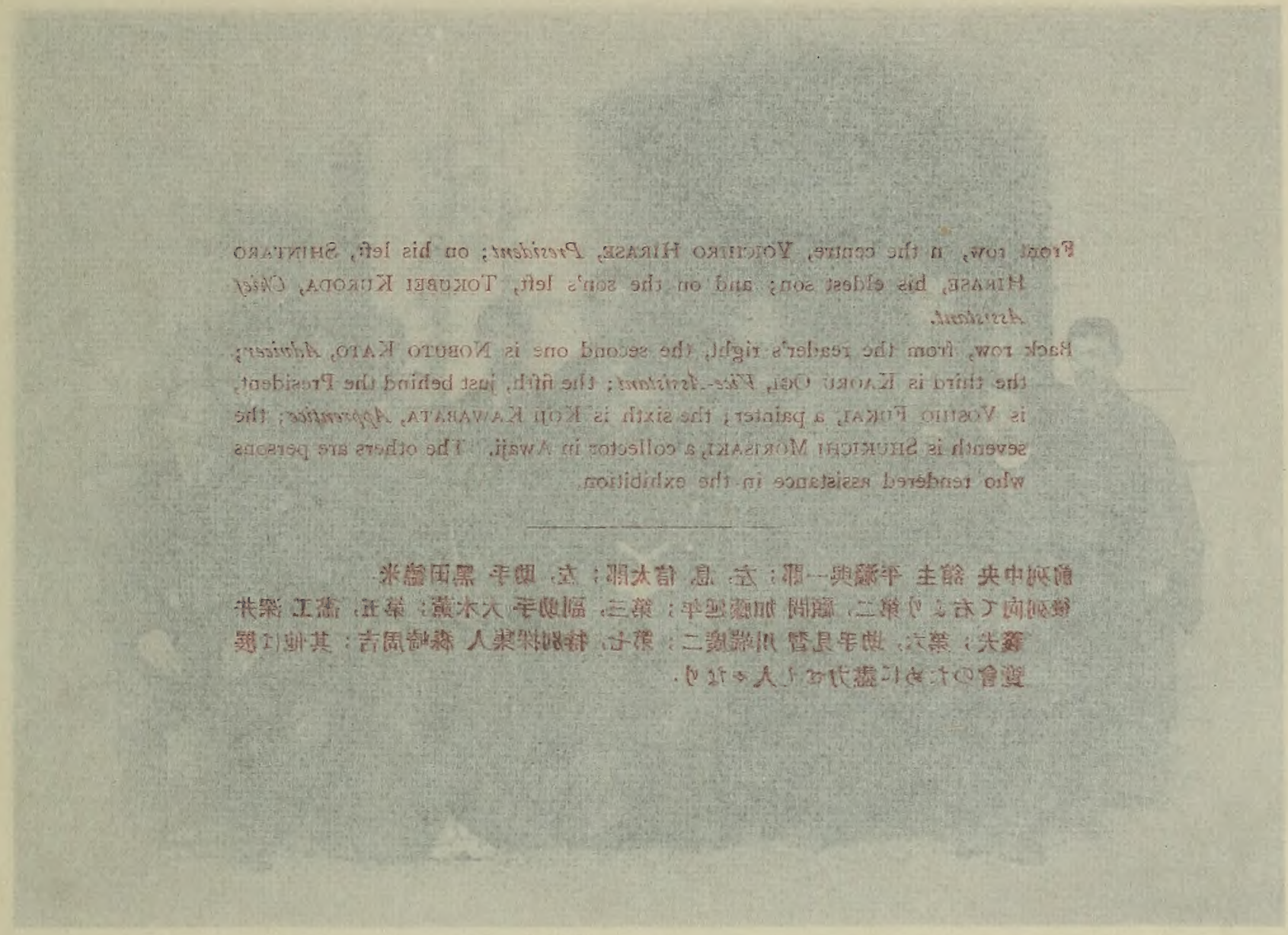



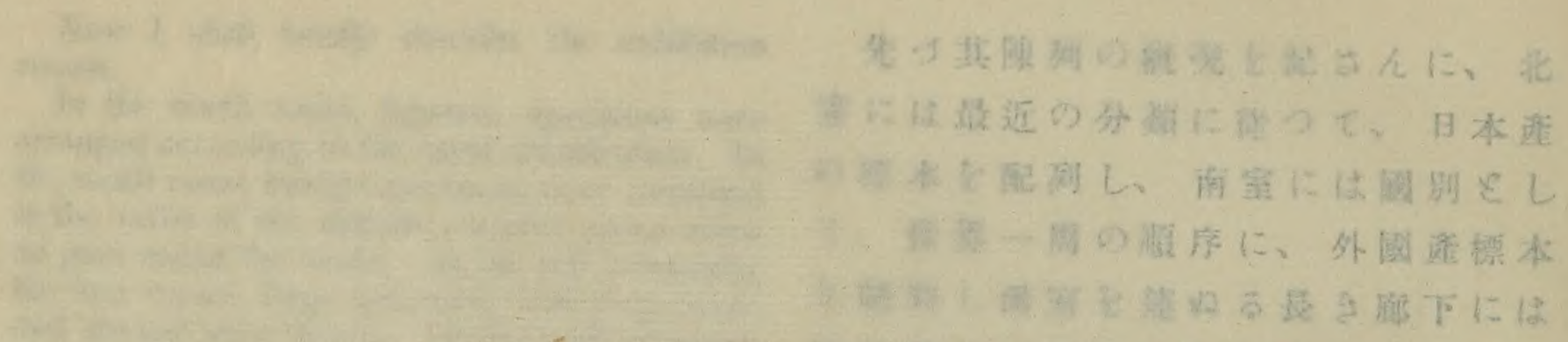

Front row, n the centre, YoIchiro HIRASe, President; on his lefi, Shintaro Hirase, his eldest son; and on the son's left, Tokubei Kuroda, Chiej Assistant.

Rack row, Prom the reader's right, the second one is NoBUto KaTO, Advicer; the third is KAORU OGI, Vice-Assistant; the fifth, just behind the President, is Yoshio FukaI, a painter; the sixth is KojI Kawabata, Apprentice; the seventh is SHUKICHI MORISAKI, a collector in Awaji. The others are persons who rendered assistance in the exhibition.

4.tis (15 而秘 传. 七福圆

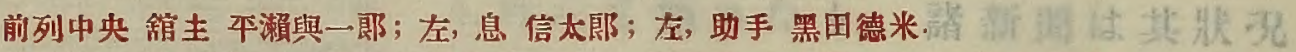

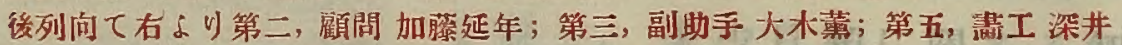
義夫；第六，助手見否川端廣二；第七，特别探集人 森崎周吉；其他に展 覽會のために蓝力せし人ゃはり。 


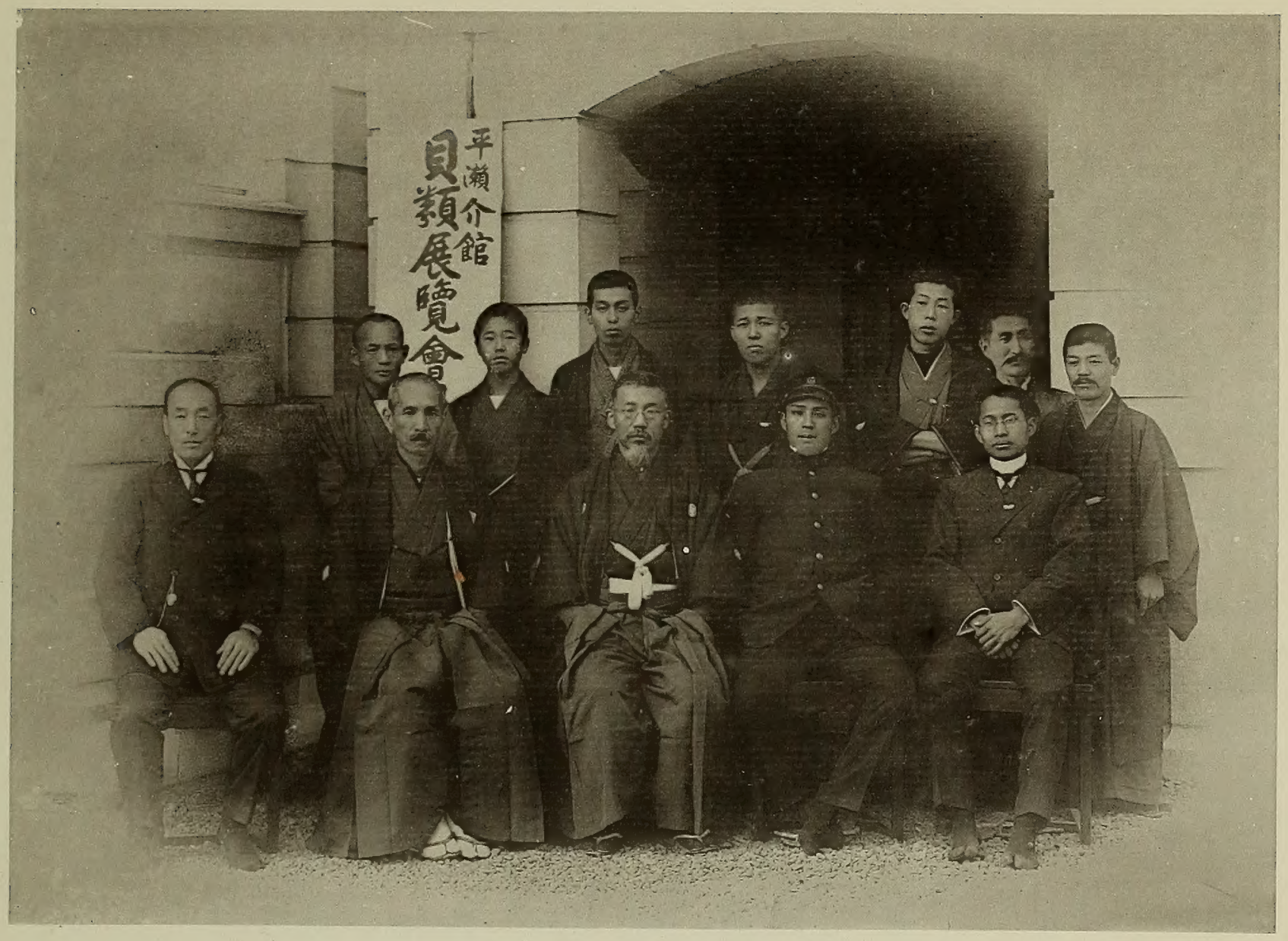


est
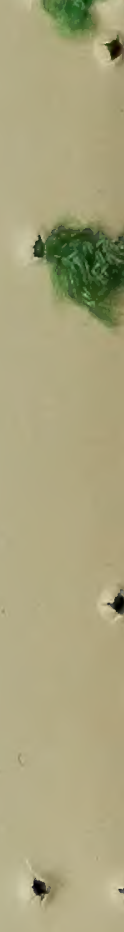

$+$ 
PART OF THE NORTHERN ROOM.

PART OF THE JafANese Department.

北室の一部

日本部陳列の一部 


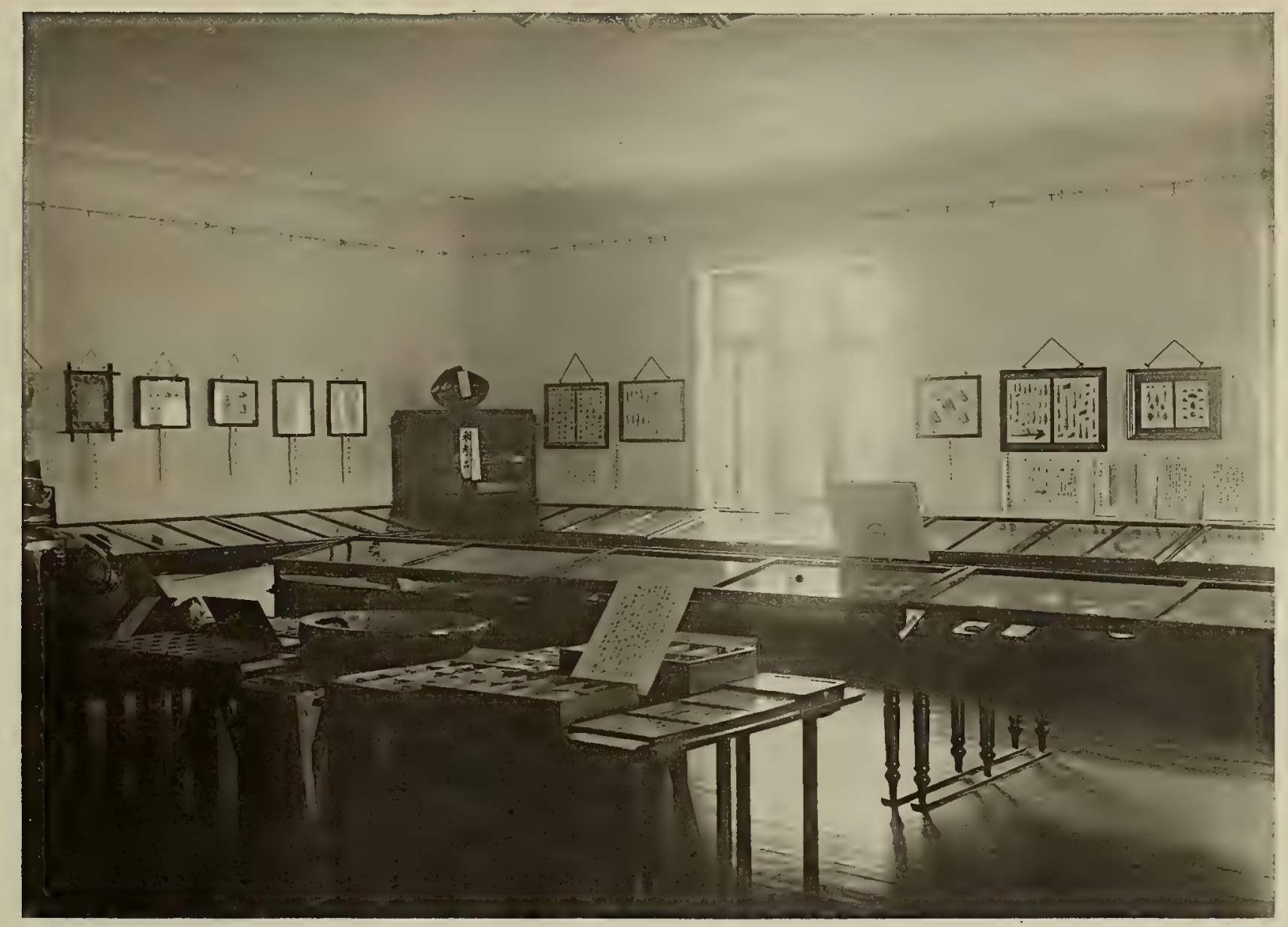


Pu

A

$\downarrow$

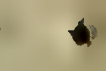

$+$ 


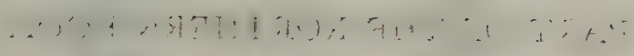

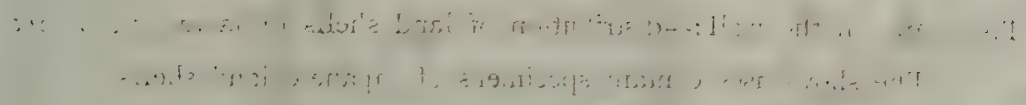

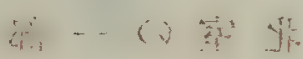

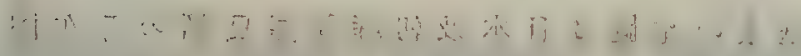

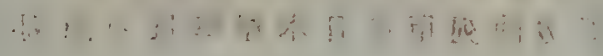


PART OF THE NORTHERN ROOM.

The maps on the wall:-distribution of land shells in Japan and Korea.

The show-cases contain specimens of Japanese land shells.

北室の一部

壁上の地圖江日本及朝鮮陸産具類の分布圖.

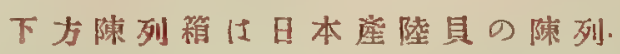




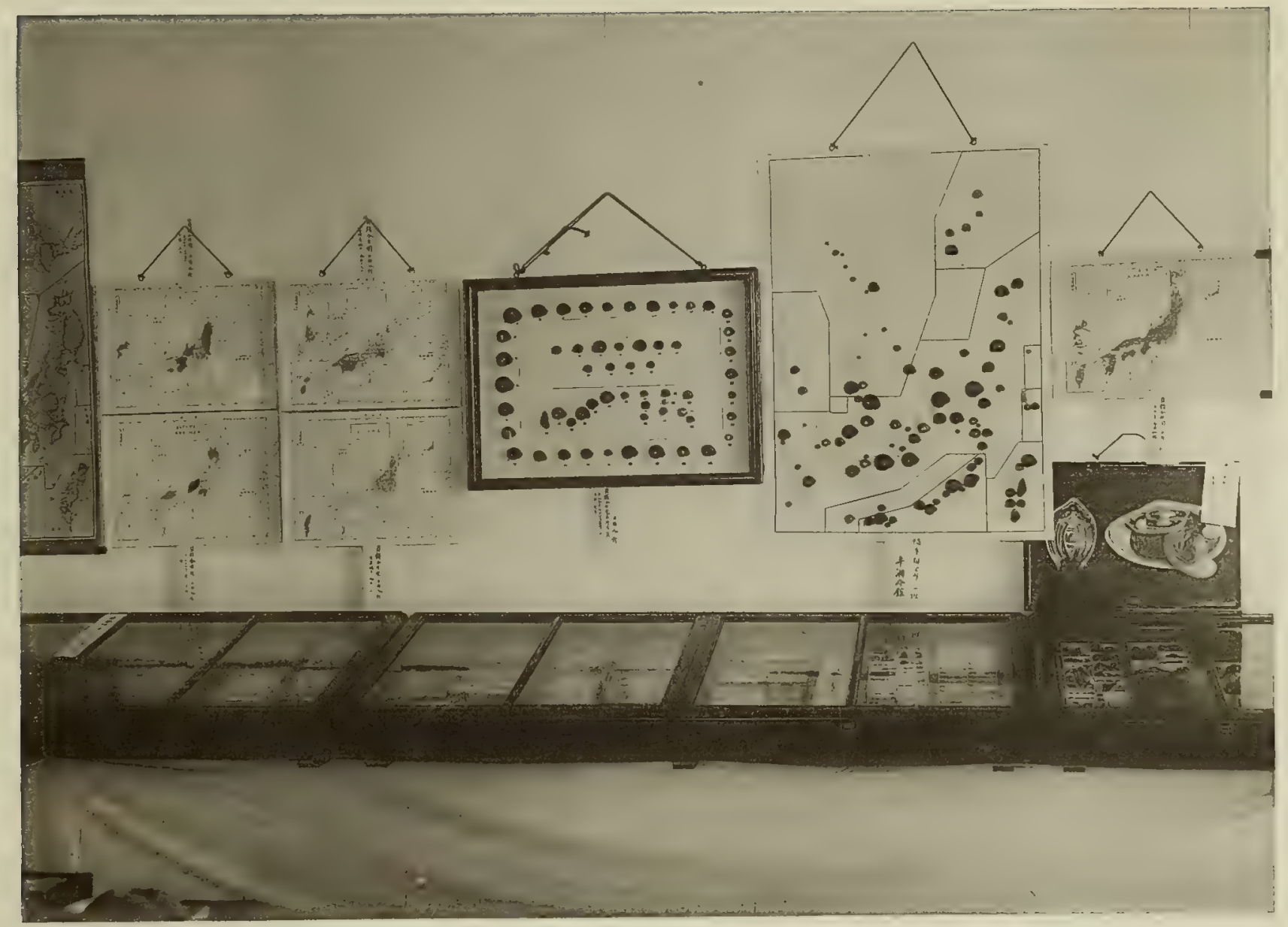


A

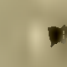

b

1 

JAPANESE RARE SHELLS.

Three species of Voluta, Spondylus regius, two large Scaln, Murex pinnatus, Buccinum inclytum, two Chrjsodomus.

Three species of Pleurotomaria.

稀 具

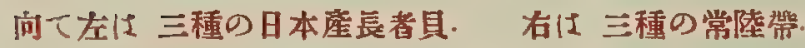

二種の絲挂貝,二種のエジボラ類っバャウが七，

七モマキバイ及猩々具なり。 


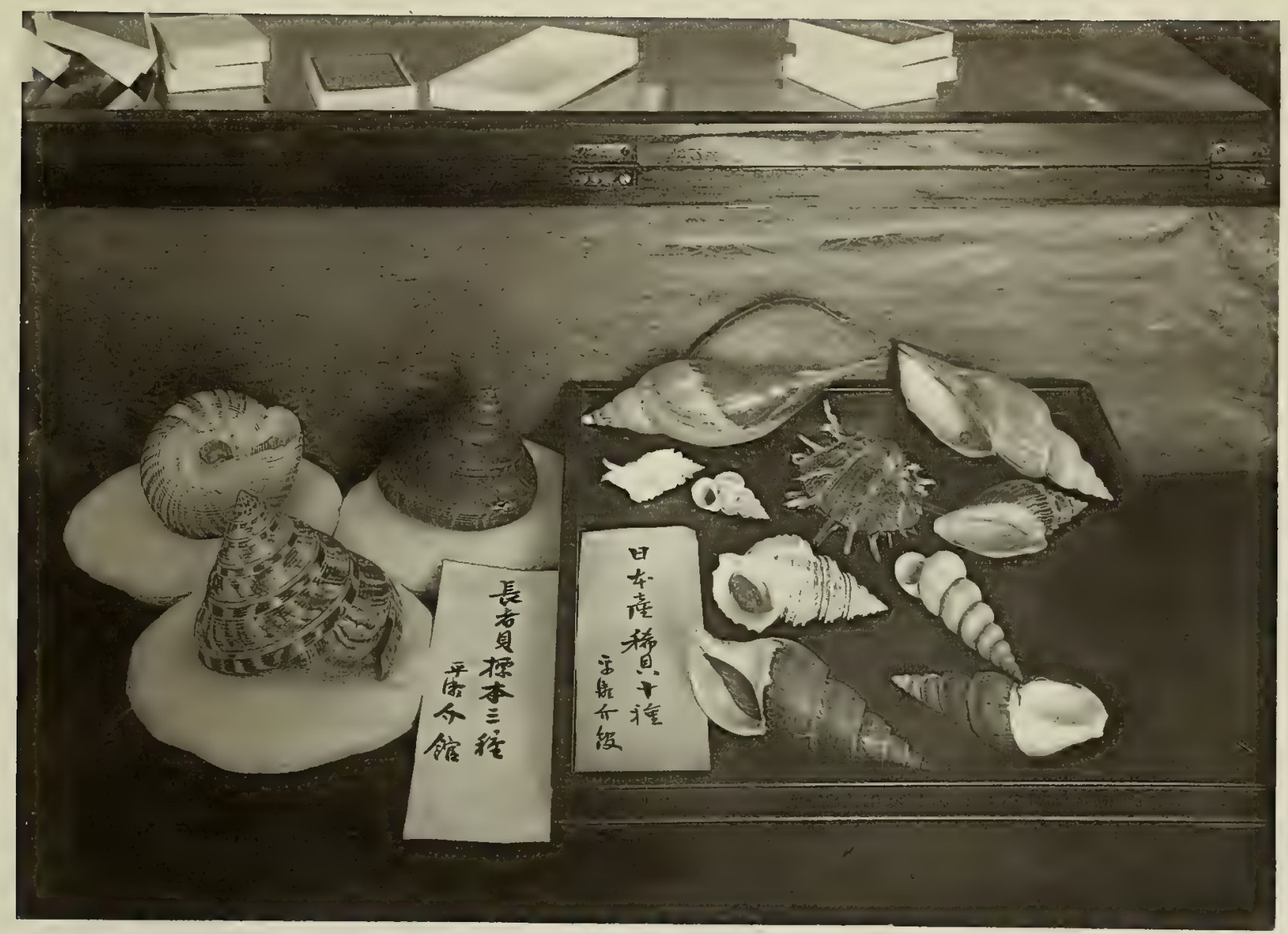


h

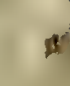

b $y$

$\lambda$

$+$ 


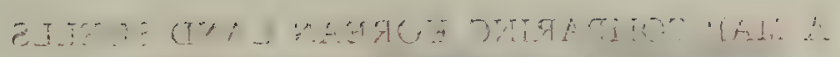

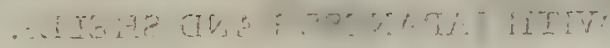

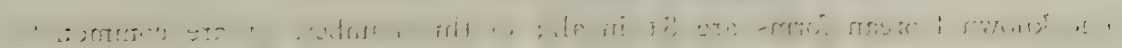

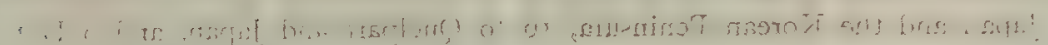
"n.

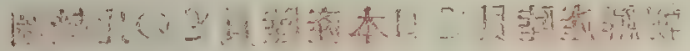

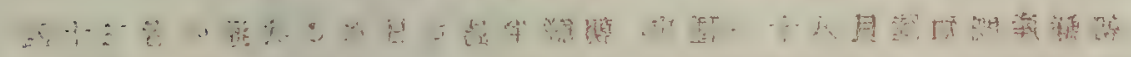

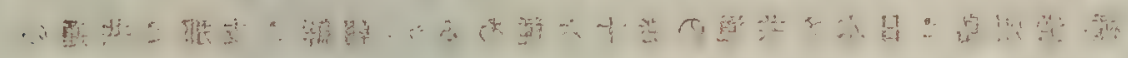

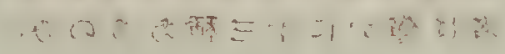




\section{A MAP COMPARING KOREAN LAND SHELLS WITH JAPANESE LAND SHELLS.}

The known Korean forms are $8 \mathbf{r}$ in all; of this number, 34 are common to Japan and the Korean Peninsula, I6 to Quelpart and Japan, and only I 3 to Korea and China.

\section{朝鮮產陸貝と日本產陸貝との比㜞圖}

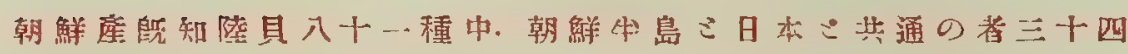

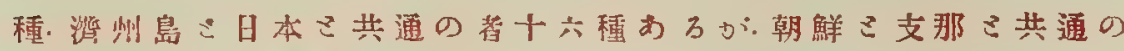
孝は僅かに十三種あるのみ. 


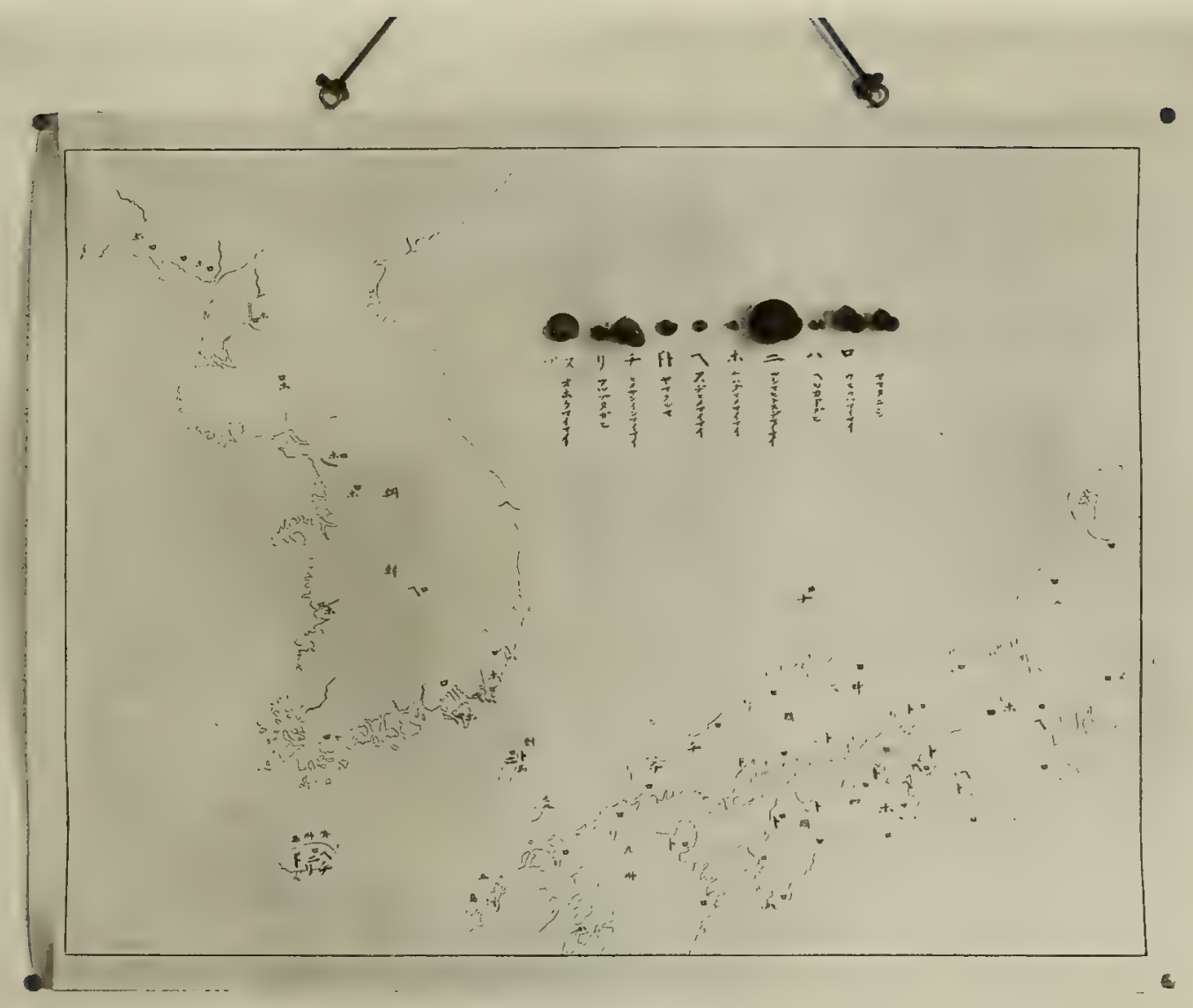


r

k $+$ 


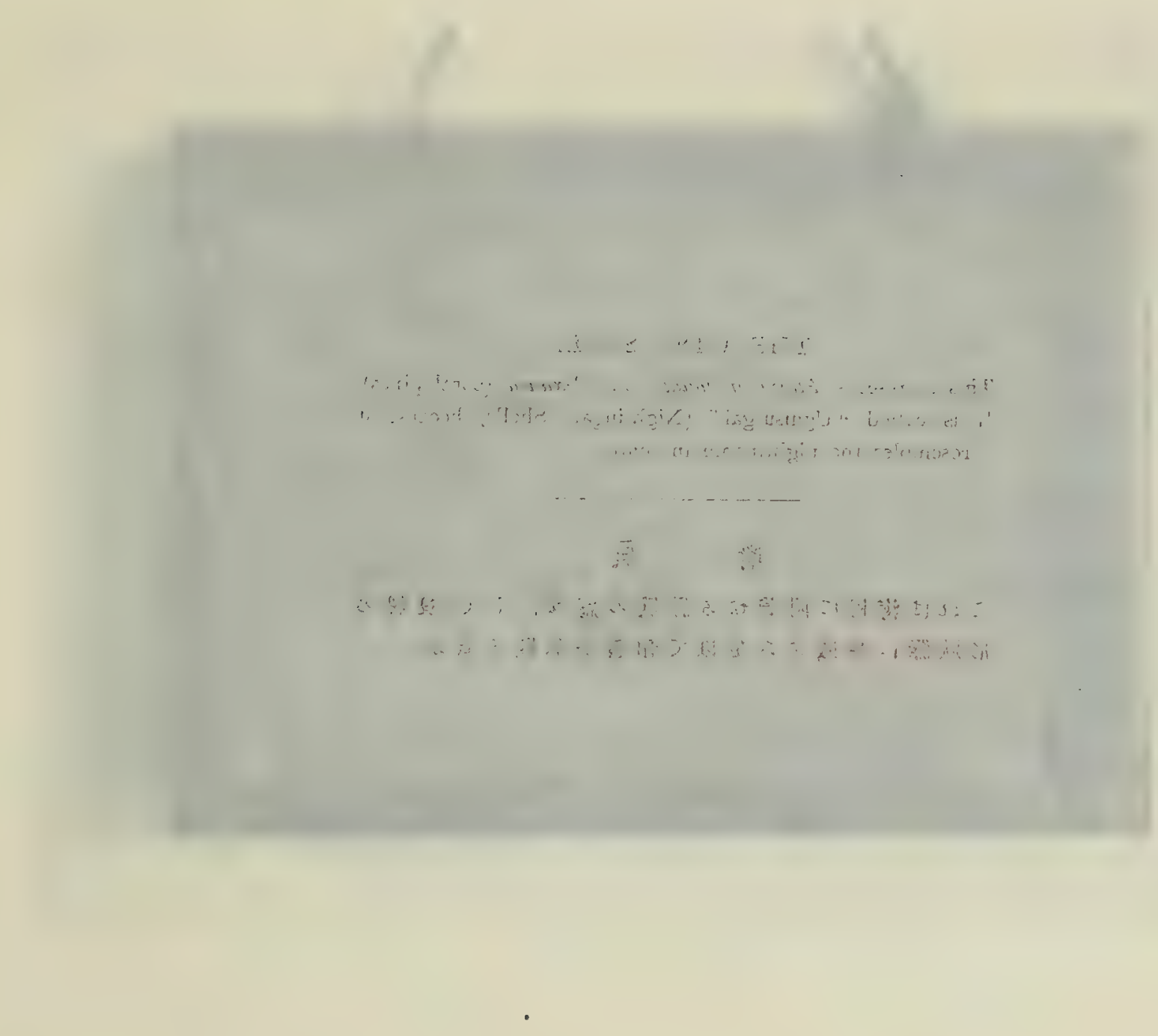


THE WING SHELL.

This represents Pteria brevialata on Plexaura (coral pines).

It is called "Uguisu-gai" (Nightingale Shell), because it resembles the nightingale in shape.

籇具

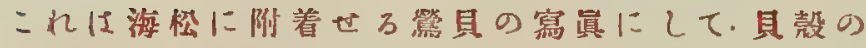

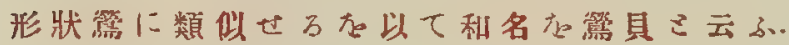




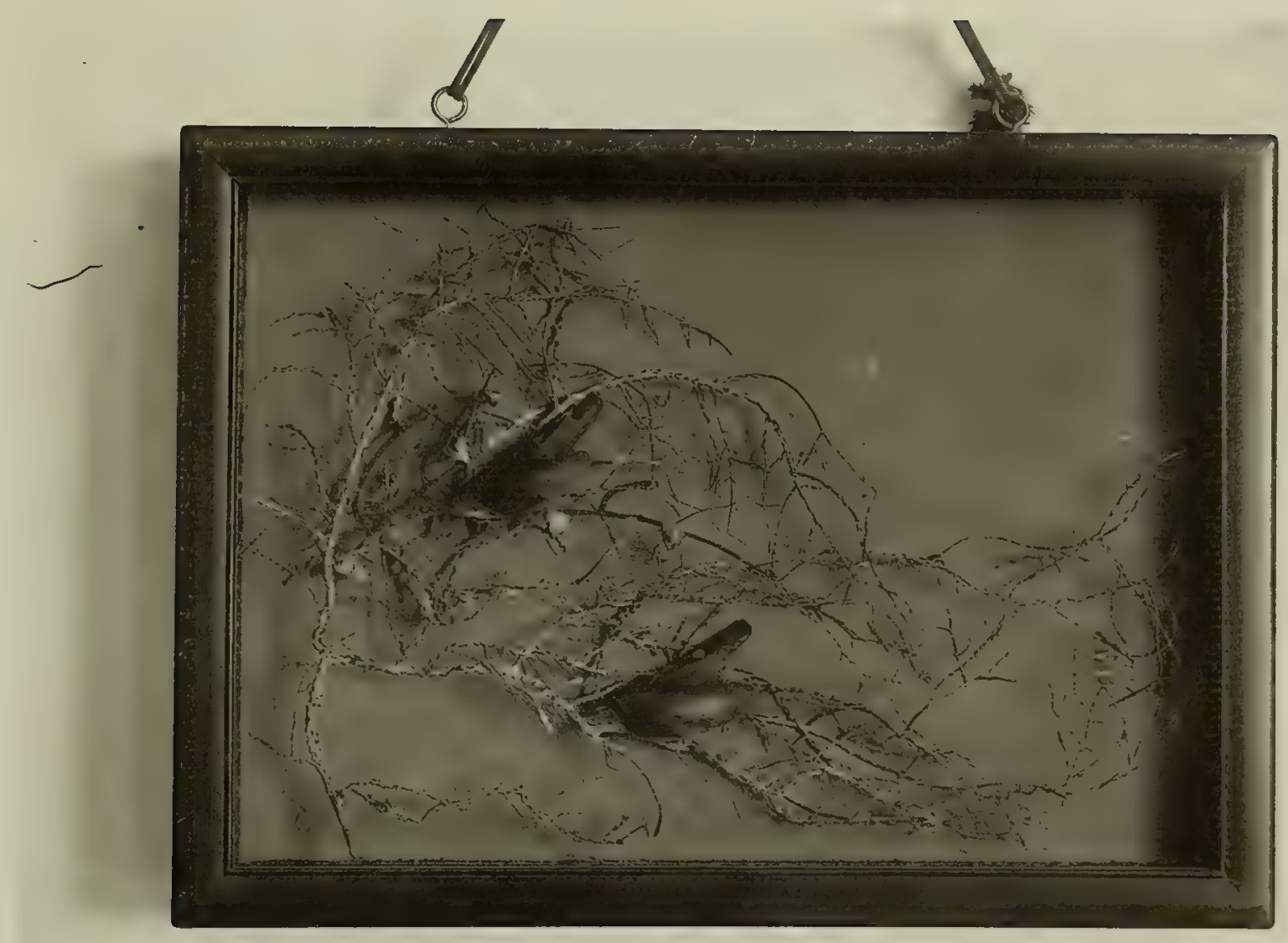




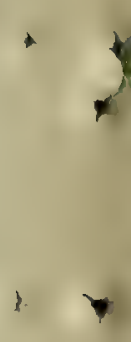

4

i

$+$

-

$+$ 



\section{FLOWER VASES AND PURSES}

The flower vases are Cones in their original forms.

The four purses were patterned after the Scallop lying beside each of them, both in shape and in design. (Both are $\mathrm{Mr}$. Hirase's new designs.)

\section{一輪挿と巾着}

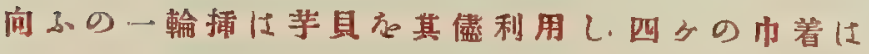

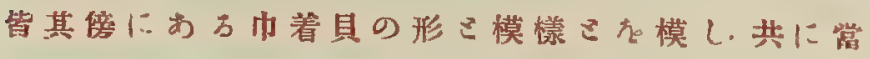
平類介館の新案に係る。 


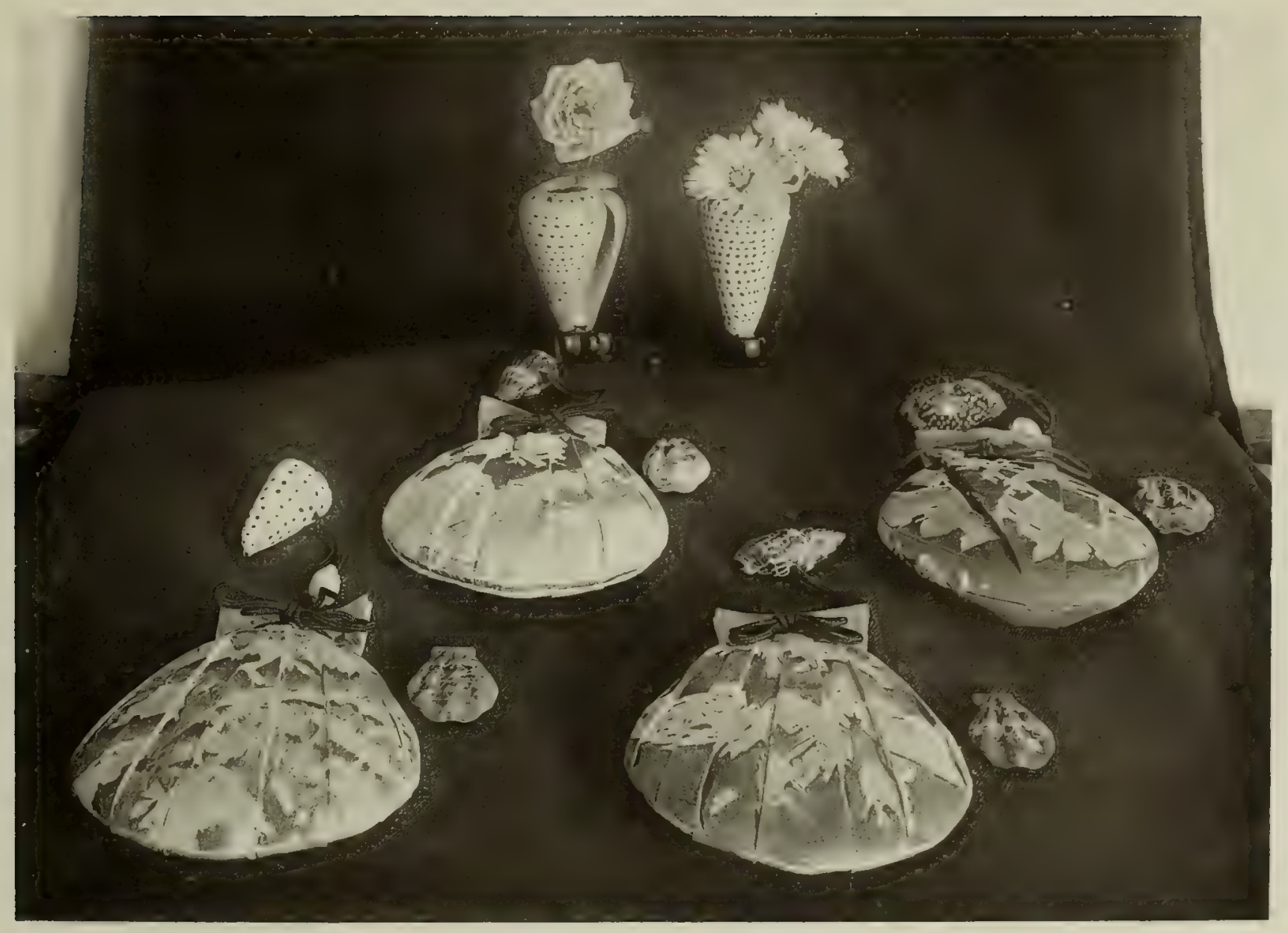


4

*

$\gamma$

$+$

$+$ 


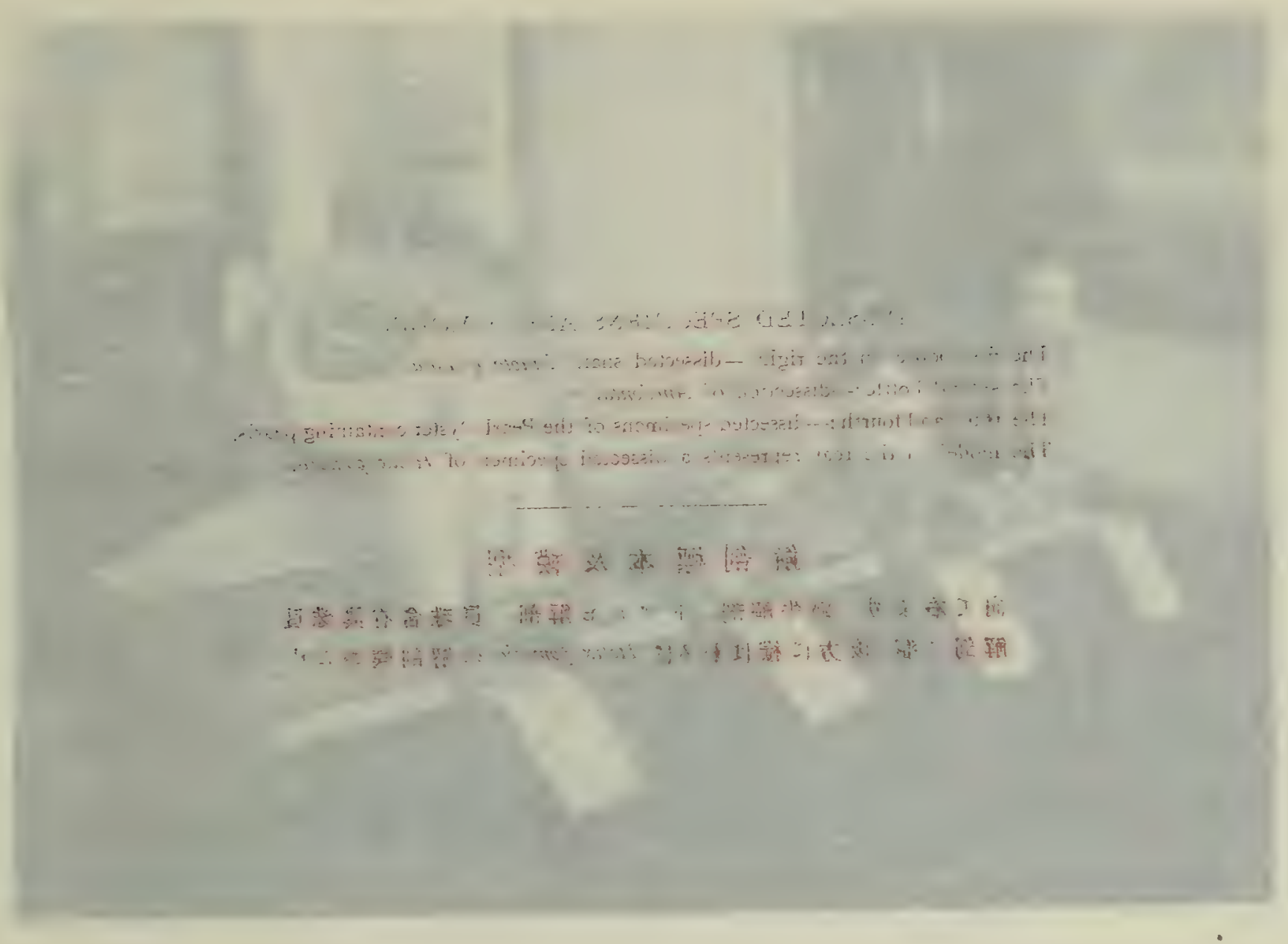


DISSECTED SPECIMENS AND A MODEL.

The first bottle on the right:-dissected snail, Eulota quesita.

The second bottle:-dissection of Anodonta.

The third and fourth :-dissected specimens of the Pearl Oyster containing pearls.

The model in the rear represents a dissected specimen of Helix pamatia.

\section{解剖標本及模型}

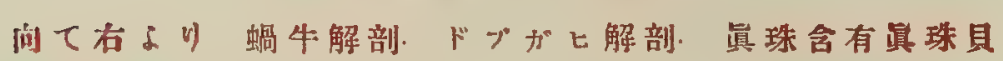
解䣋二瓶。後力に橫はんるはHelix pomatia の解剖模型なり。 


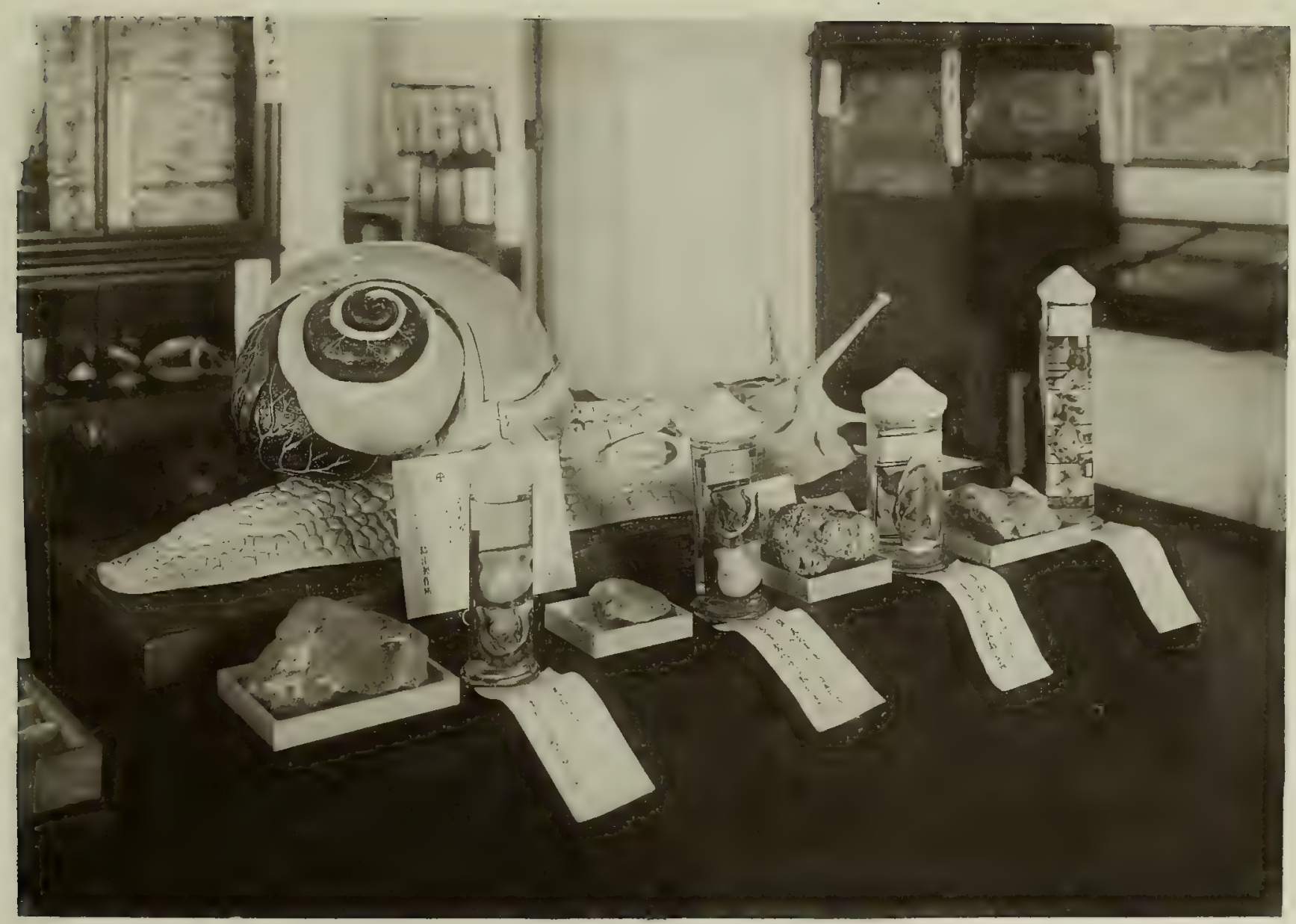




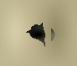

4

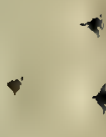




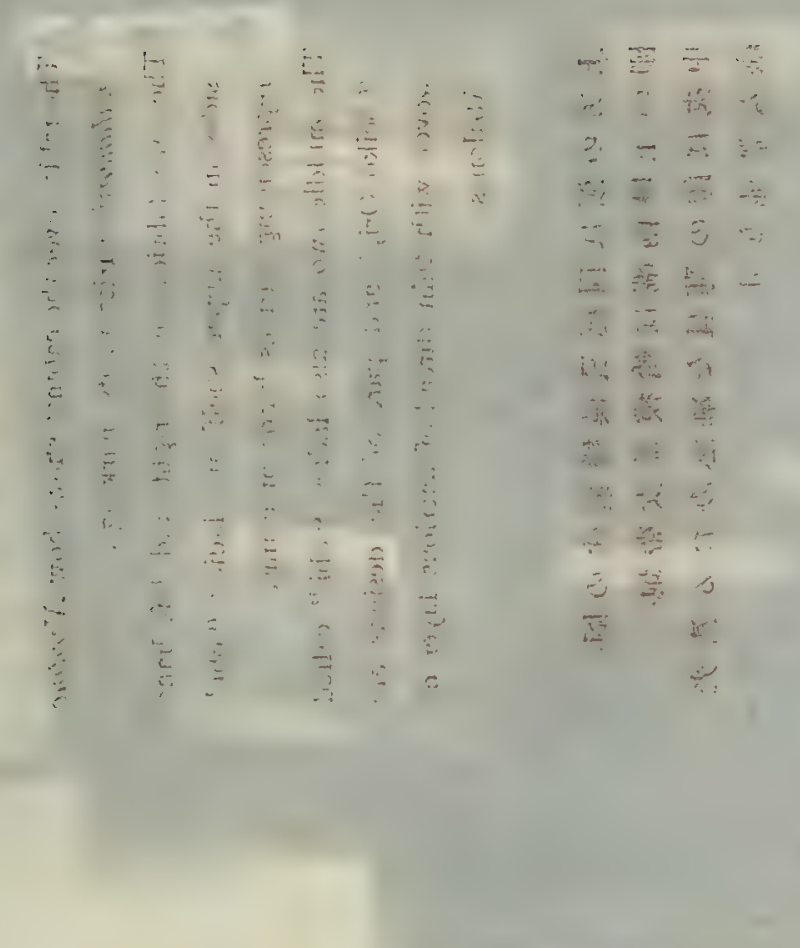




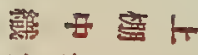

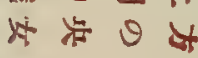

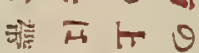

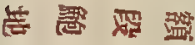

$$
\begin{aligned}
& \text { क } \theta \text { 풴 }
\end{aligned}
$$

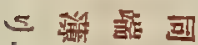

$$
\begin{aligned}
& \text { 证西满 }
\end{aligned}
$$

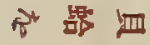

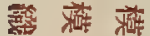

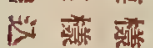

$$
\begin{aligned}
& \text { \% 好蹬 } \\
& \text { 潇 } \\
& 0 \\
& \text { 解 国 }
\end{aligned}
$$

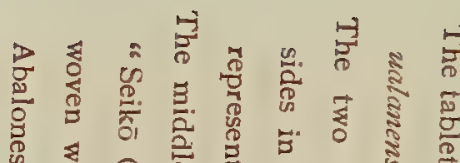

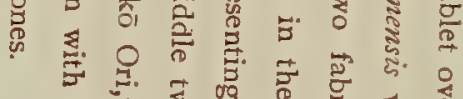

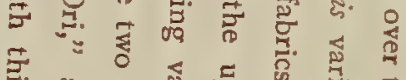

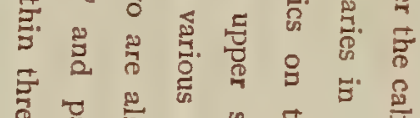

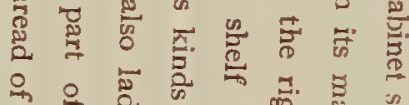

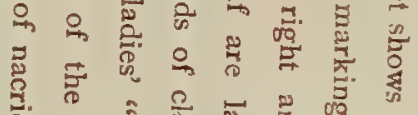

$$
\begin{aligned}
& \text { ส. }
\end{aligned}
$$

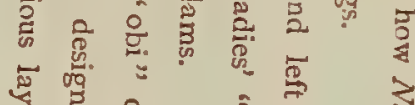

$$
\begin{aligned}
& \text { * }
\end{aligned}
$$




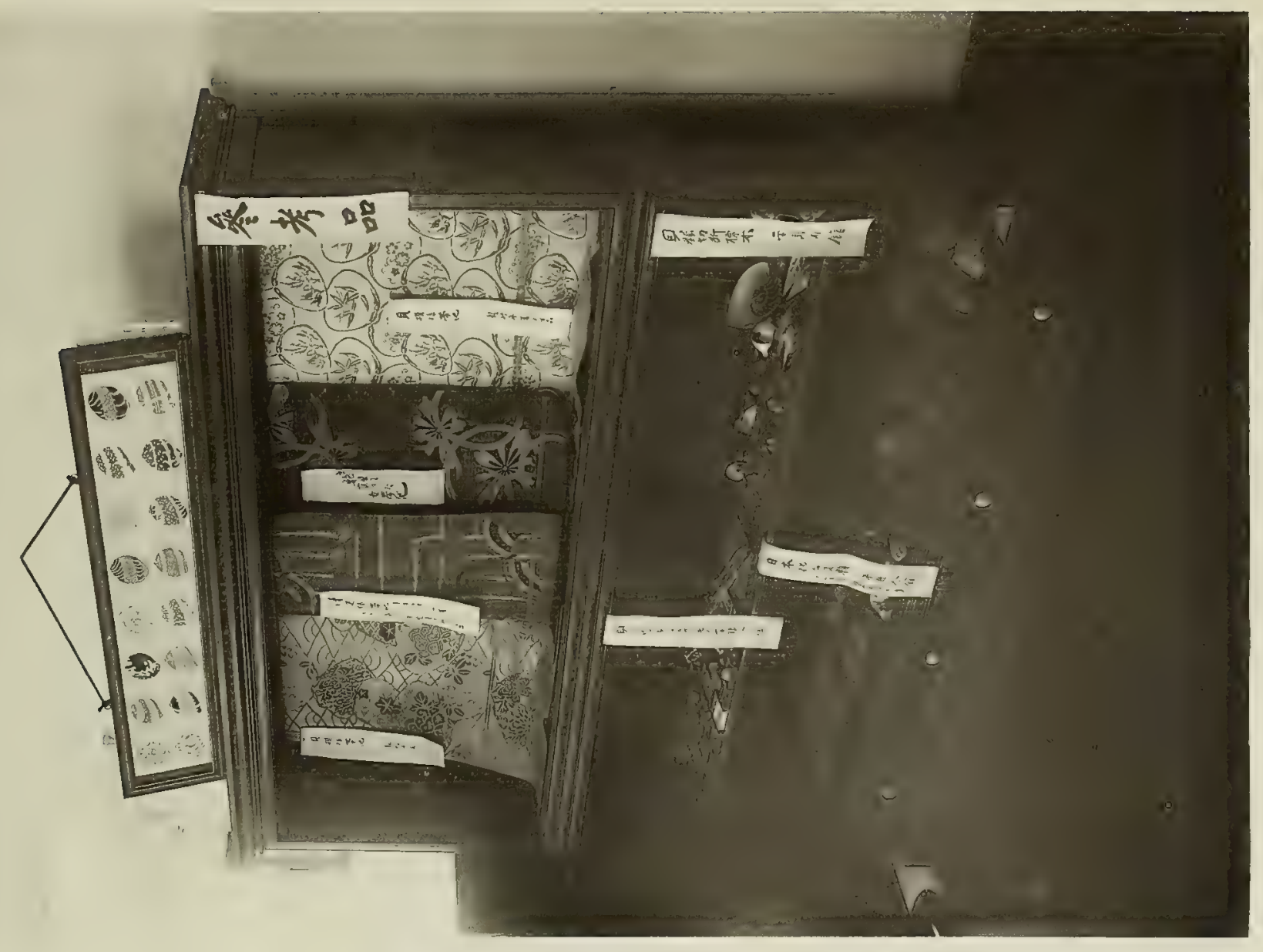


$\downarrow$

$+$

$+$ 


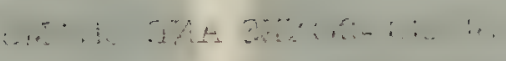

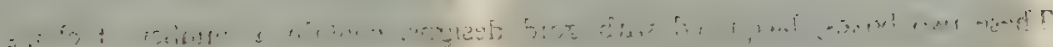

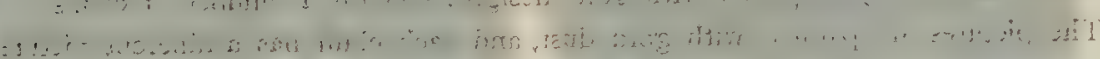

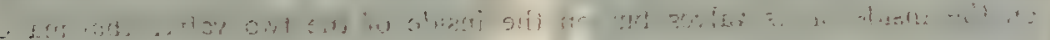
(instisicy a

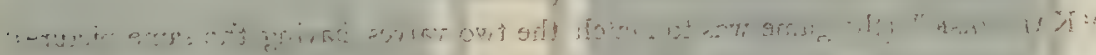

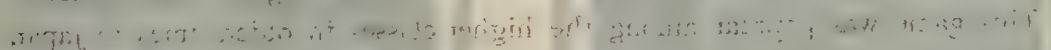

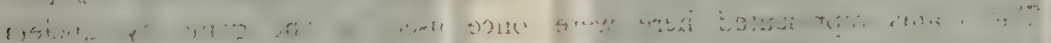
ध,

$$
\text { I. } 3 .
$$


SHELL-BOXES AND CLAMS.

These two boxes, lacquered with gold designs, contain a number of clams.

The pictures are painted with gold dust, and each clam has a different picture on the inside of its valves, but on the inside of the two valves that make up one clam the same picture is painted.

"KAIAWASE" (the game was to match the two valves having the same pictures). This game was popular among the higher classes in olden times in Japan. The clams represented here were once used in the game by ancient noblewomen, and show some of their elegant pictures inside.

貝桶 $\varepsilon$ 貝 


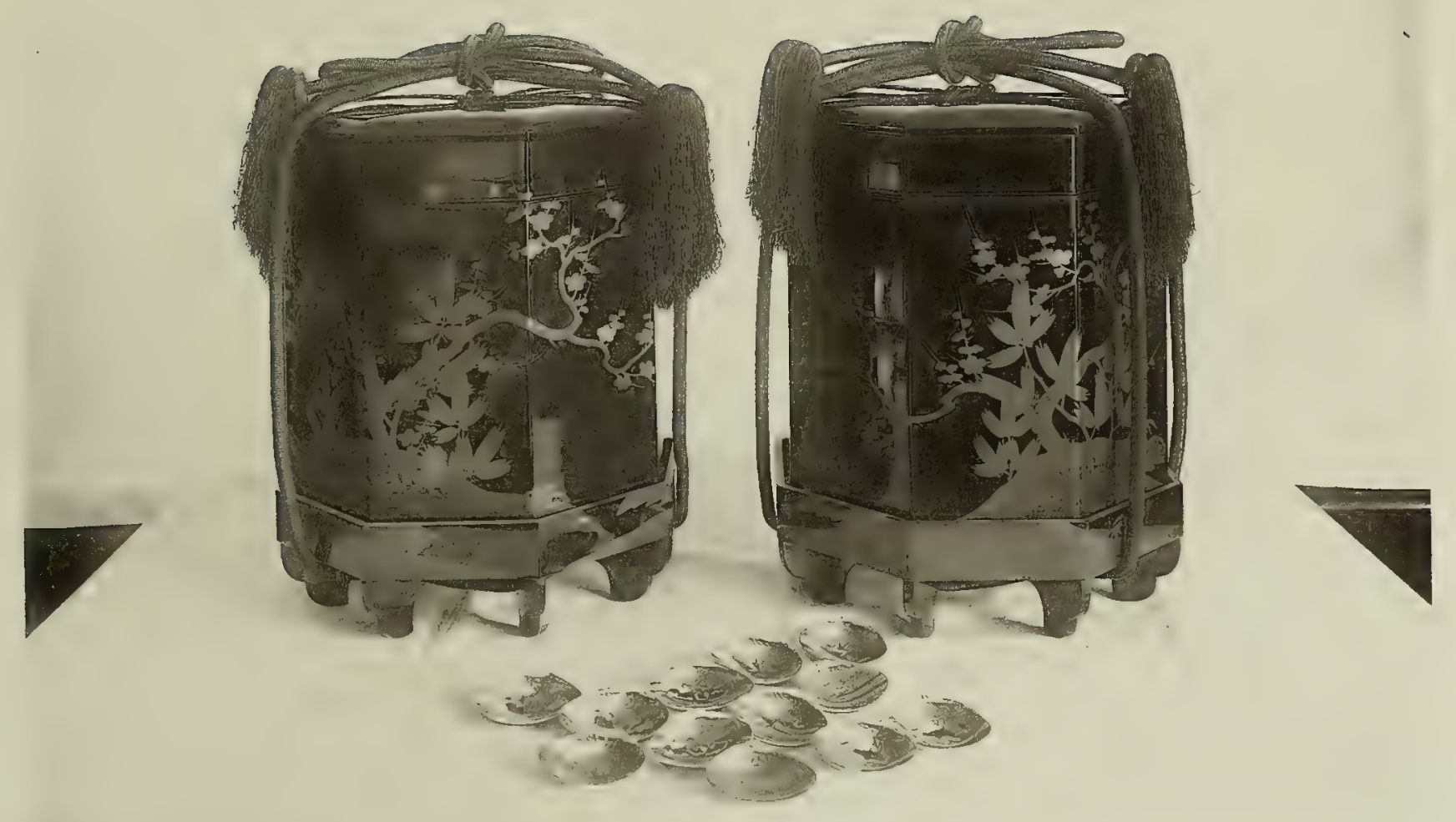


$+$

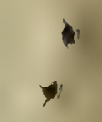

1.

4

$+$

$+$ 


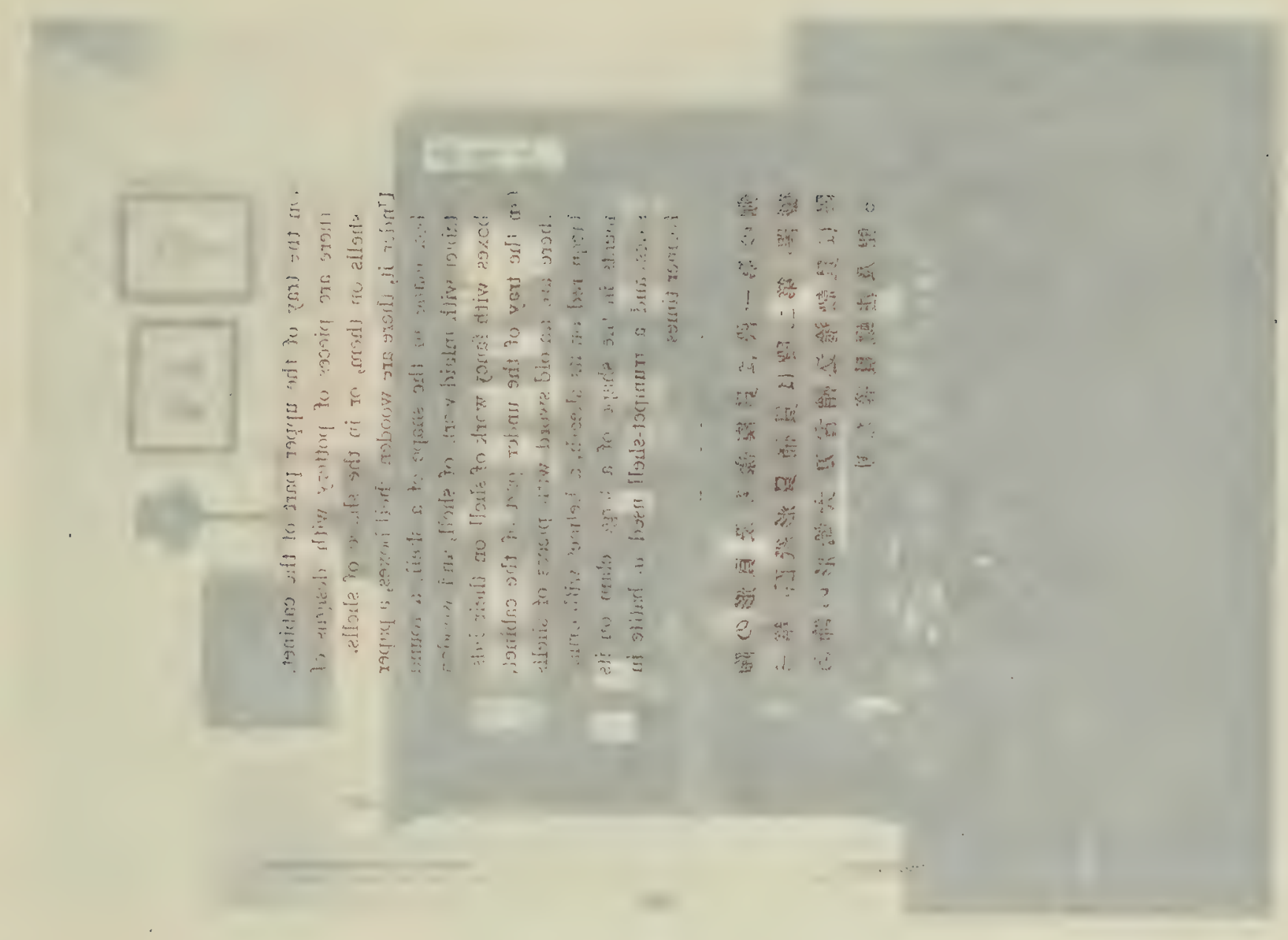




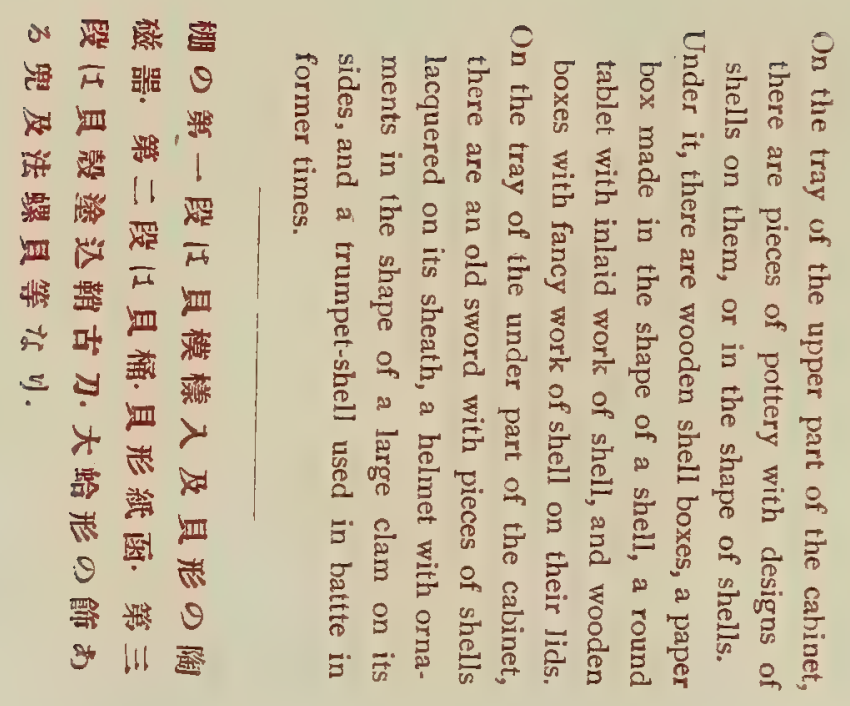




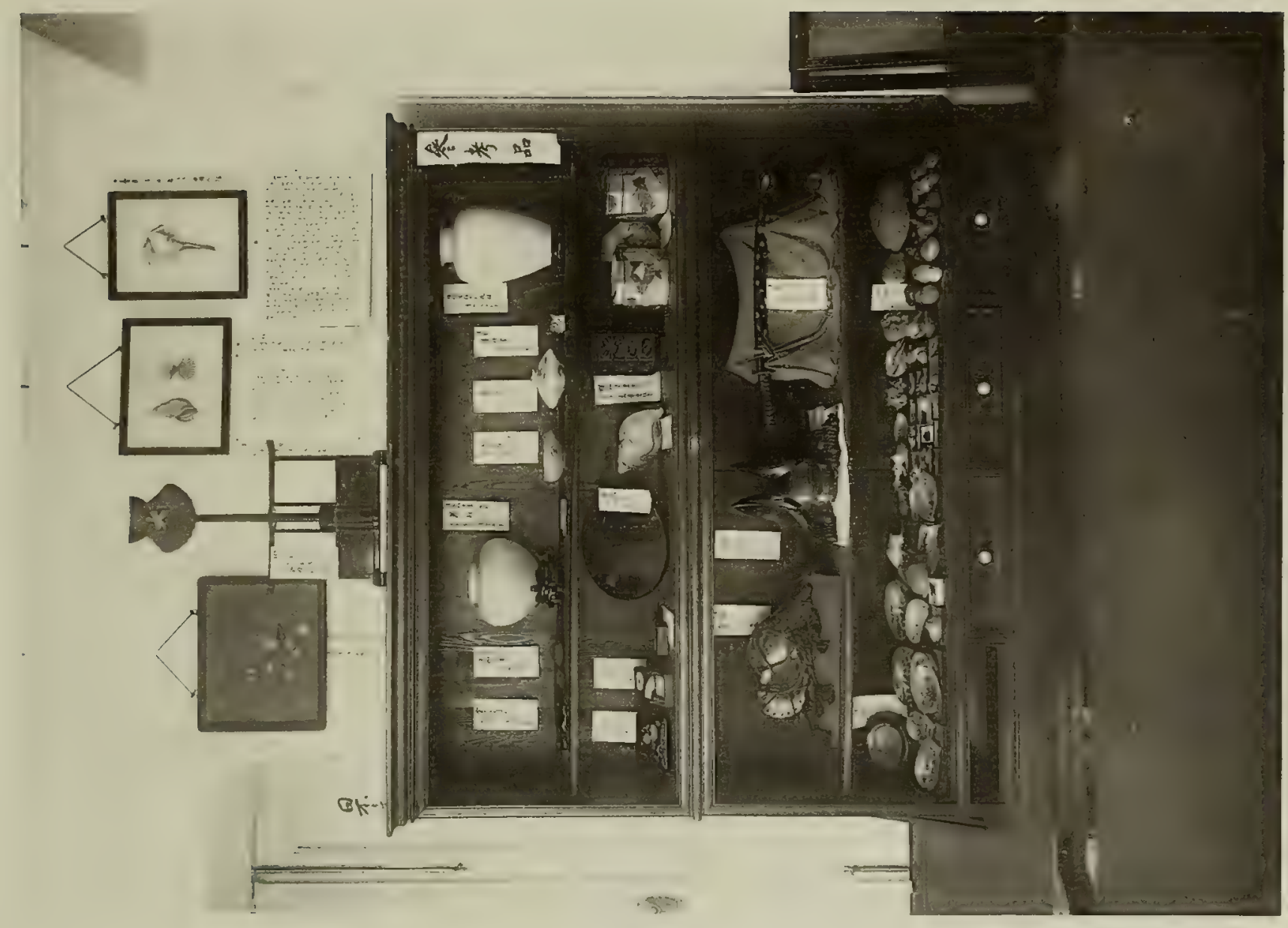




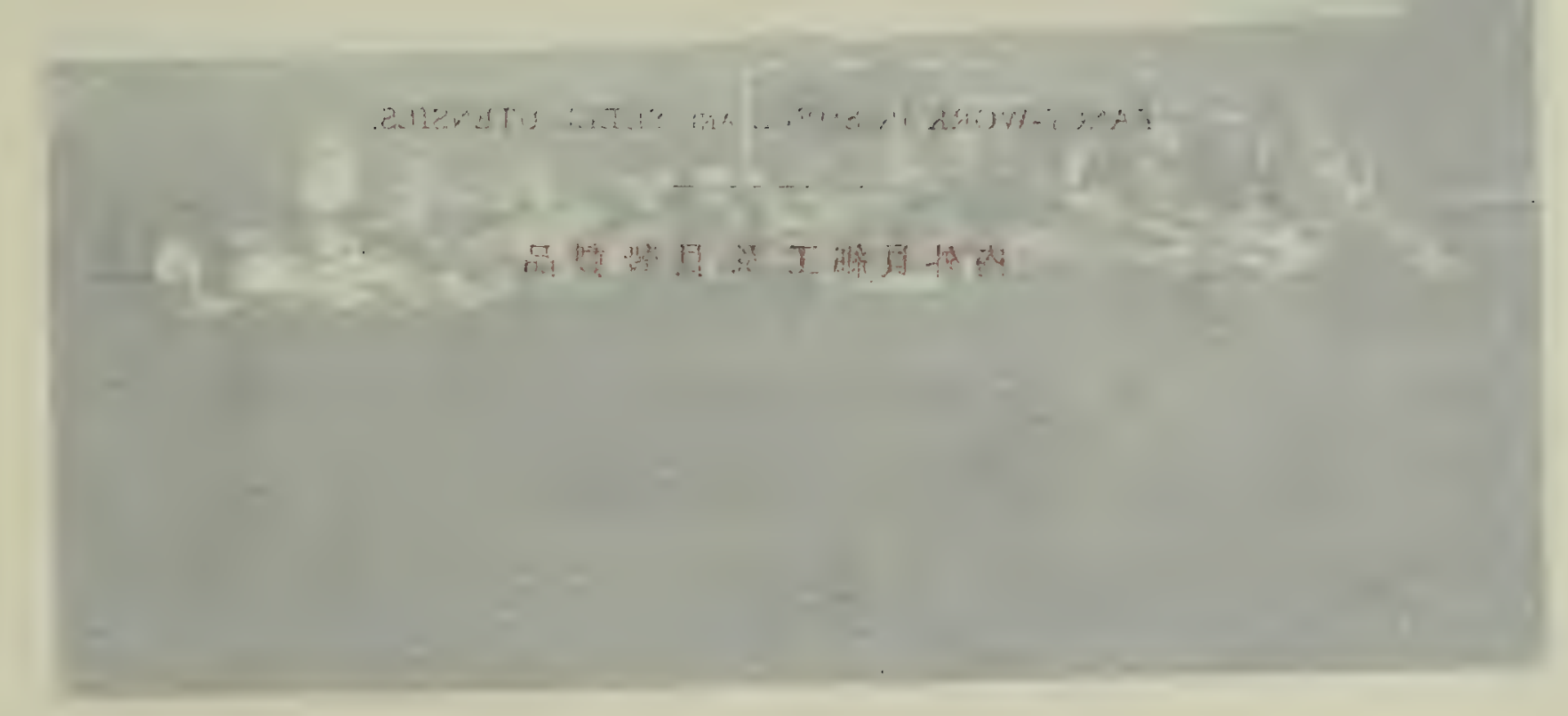


FANCY-WORK IN SHELL AND SHELL UTENSILS.

内外貝細工. 及具淑製品 


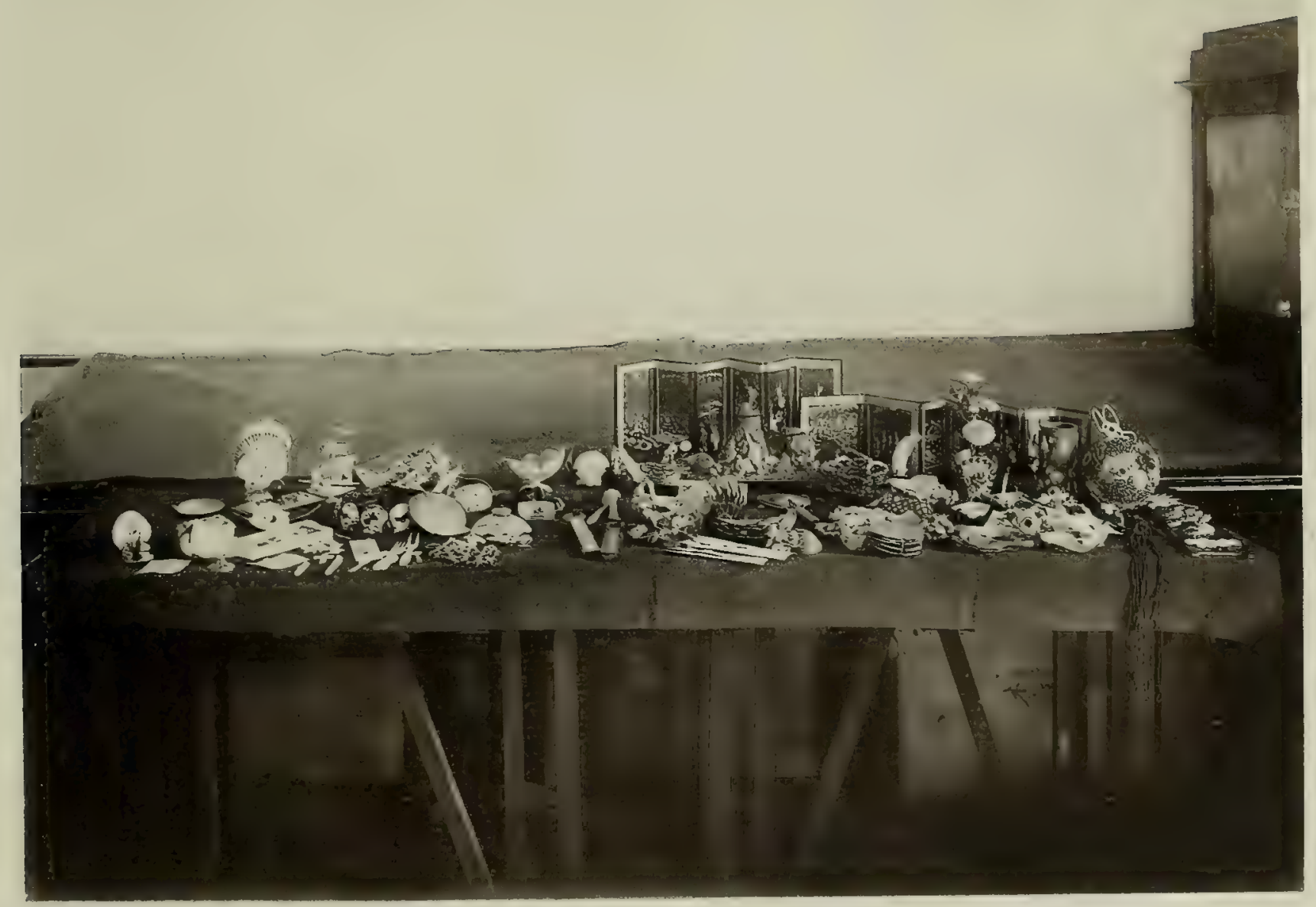




$$
4
$$



A VIEW OF THE EXHIBITION IN THE HALL.

The frames on the wall:-designs and various kinds of pictures for reference, relating to shells.

\section{廊下の像 列}

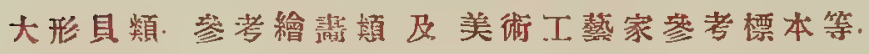




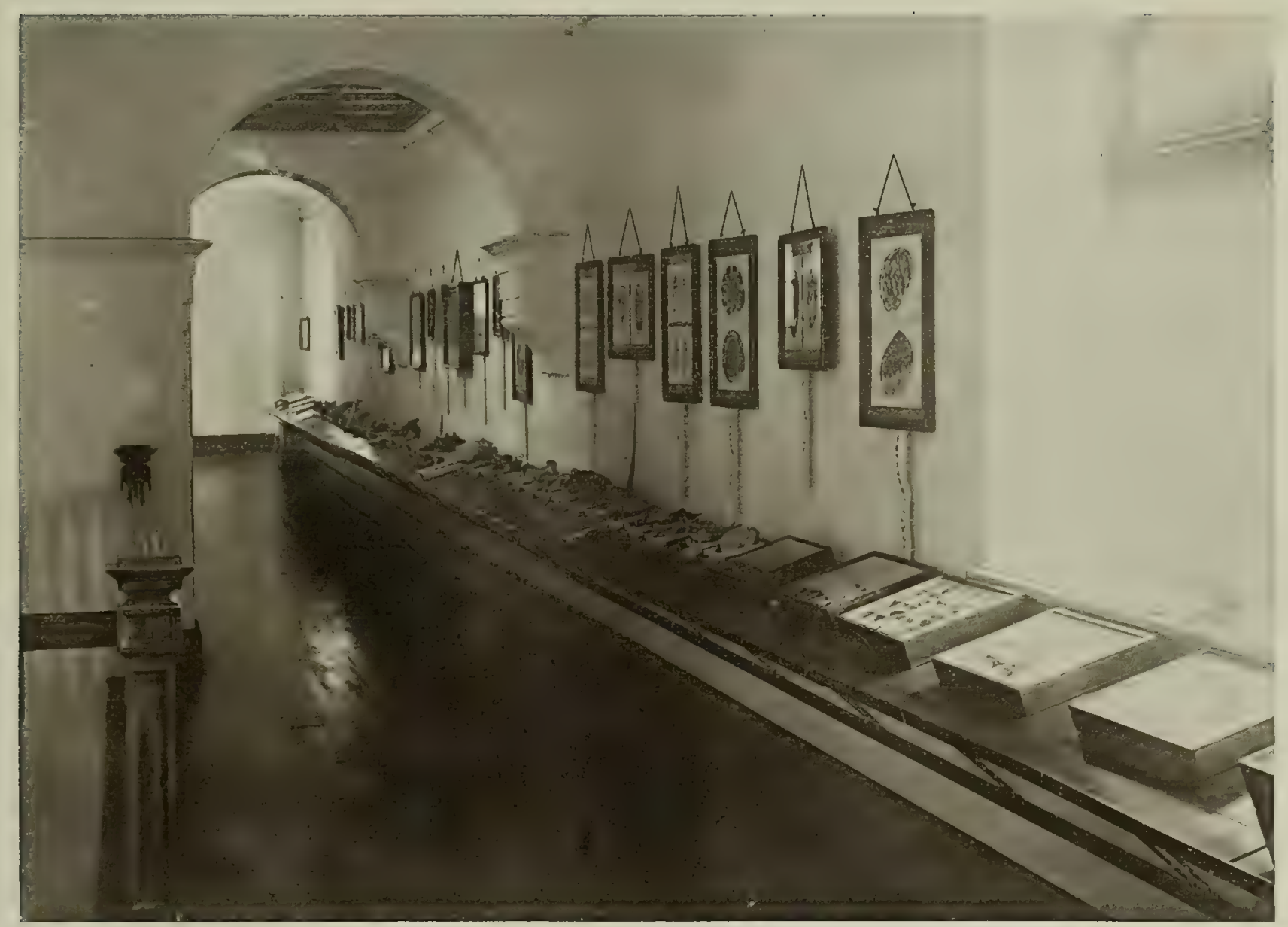


$+1$

1

६:

4

$\pi$

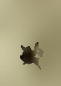




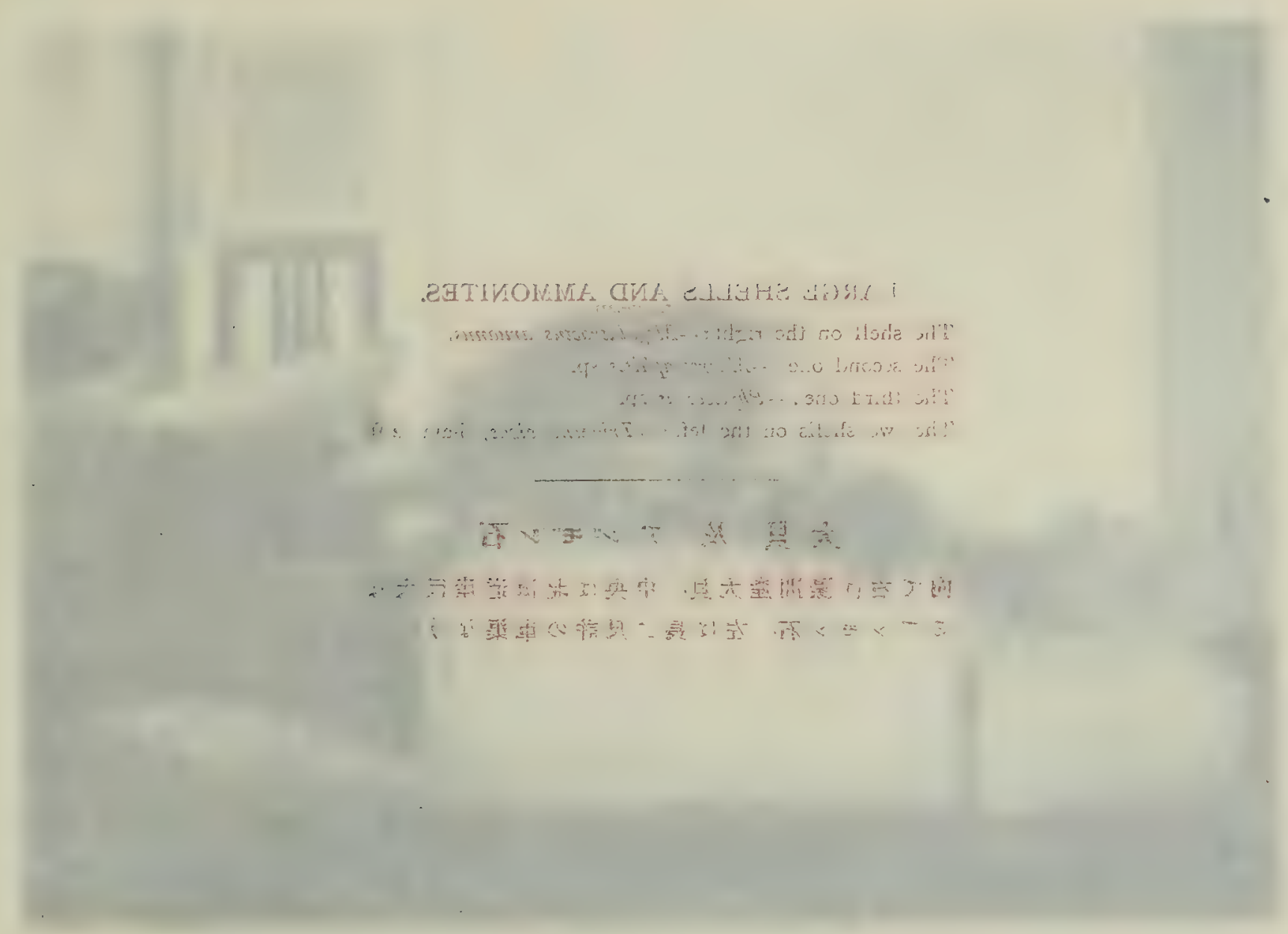




\section{LARGE SHELLS AND AMMONITES.}

The shell on the right:-Megalatractus amanus.

The second one:-Mracroscaphites sp.

The third one:-Phylloceras sp.

The two shells on the left:-Tridanna gigas, diam. $2 \mathrm{ft}$.

$$
\text { 大貝及アンモン石 }
$$

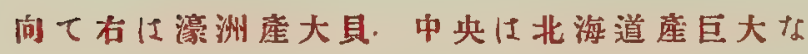
ろアンモン石. 左は長二尺話の車渠なり。 


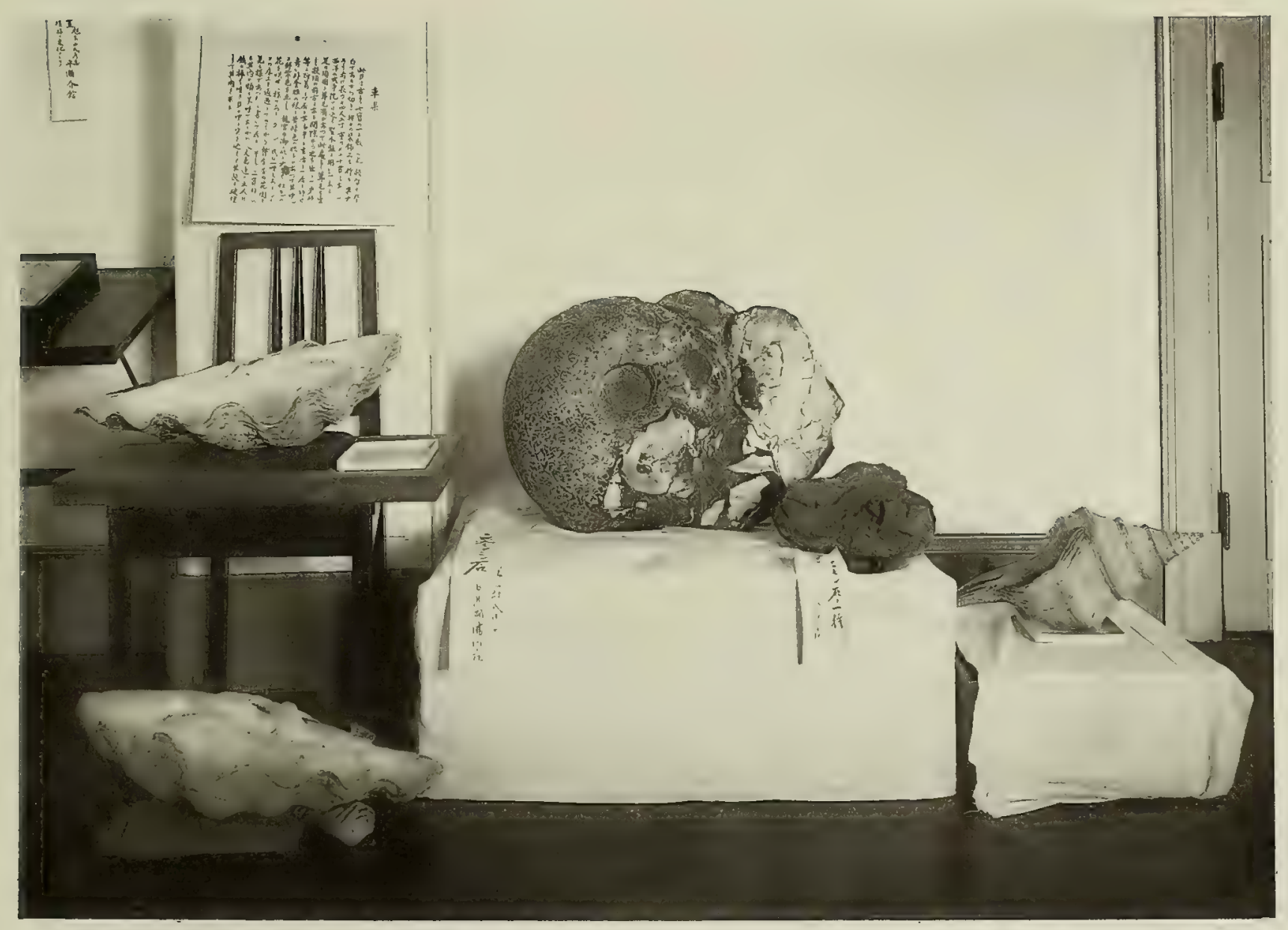


x 


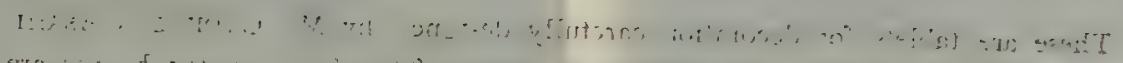

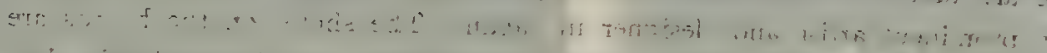
y.

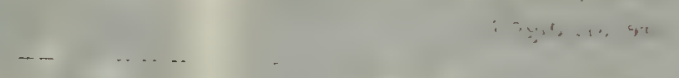

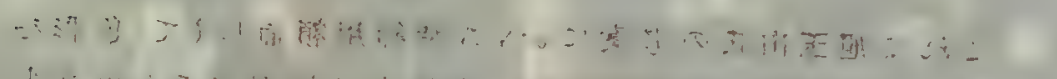

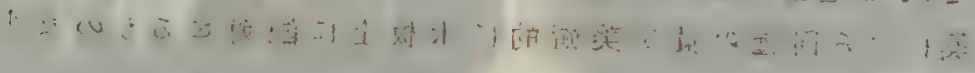


These are tablets for decoration carefully designed by Mr. GyokuzAN AsAHI, a prominent artist and designer in Tapan. The shells on the boards are Scallops of different colours. See how elegantly and harmoniously they are arranged.

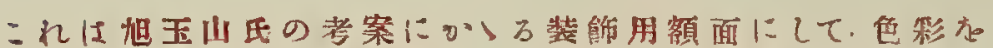
異にさ万同種》具艻美術的に板上に配列せるものなり。 

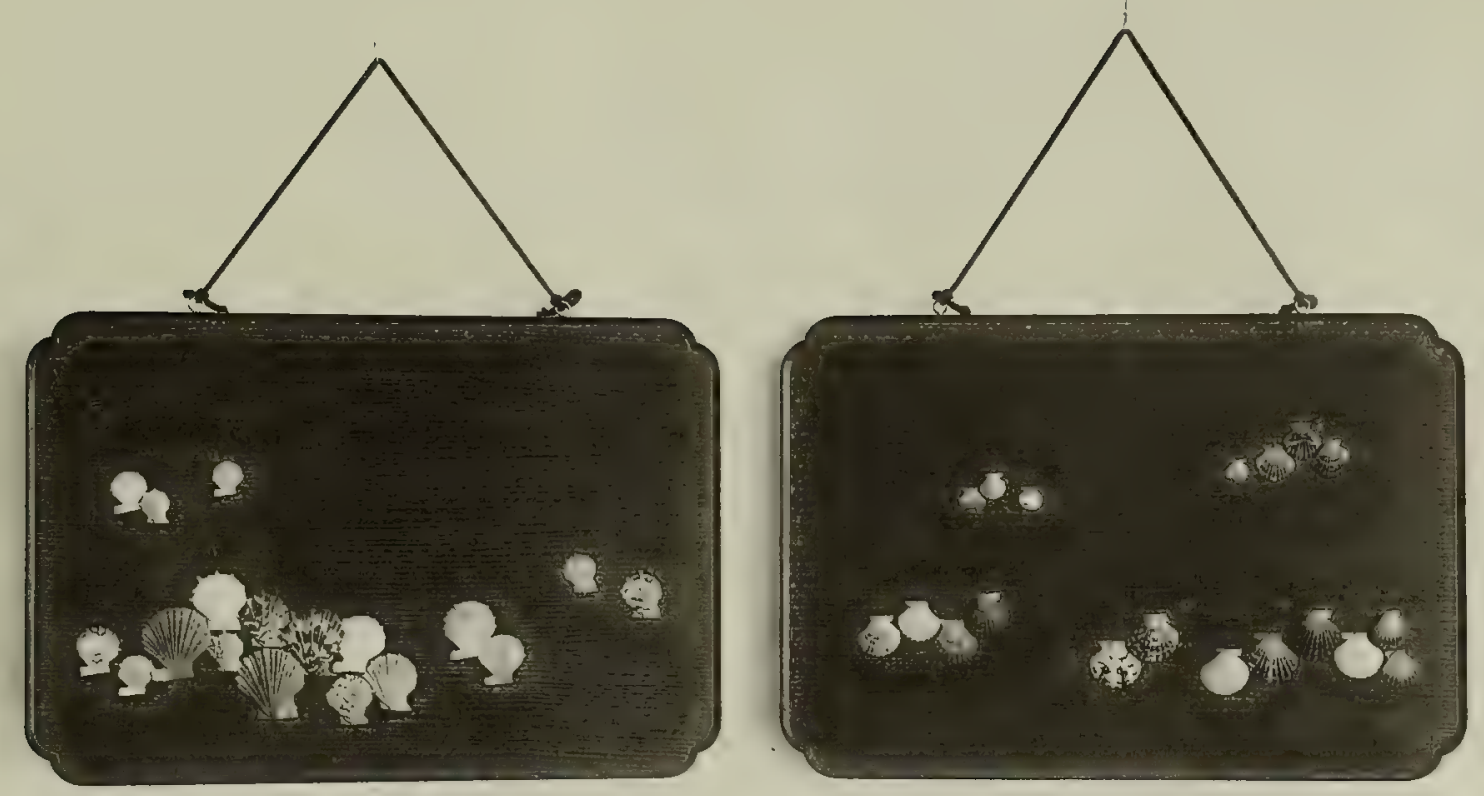


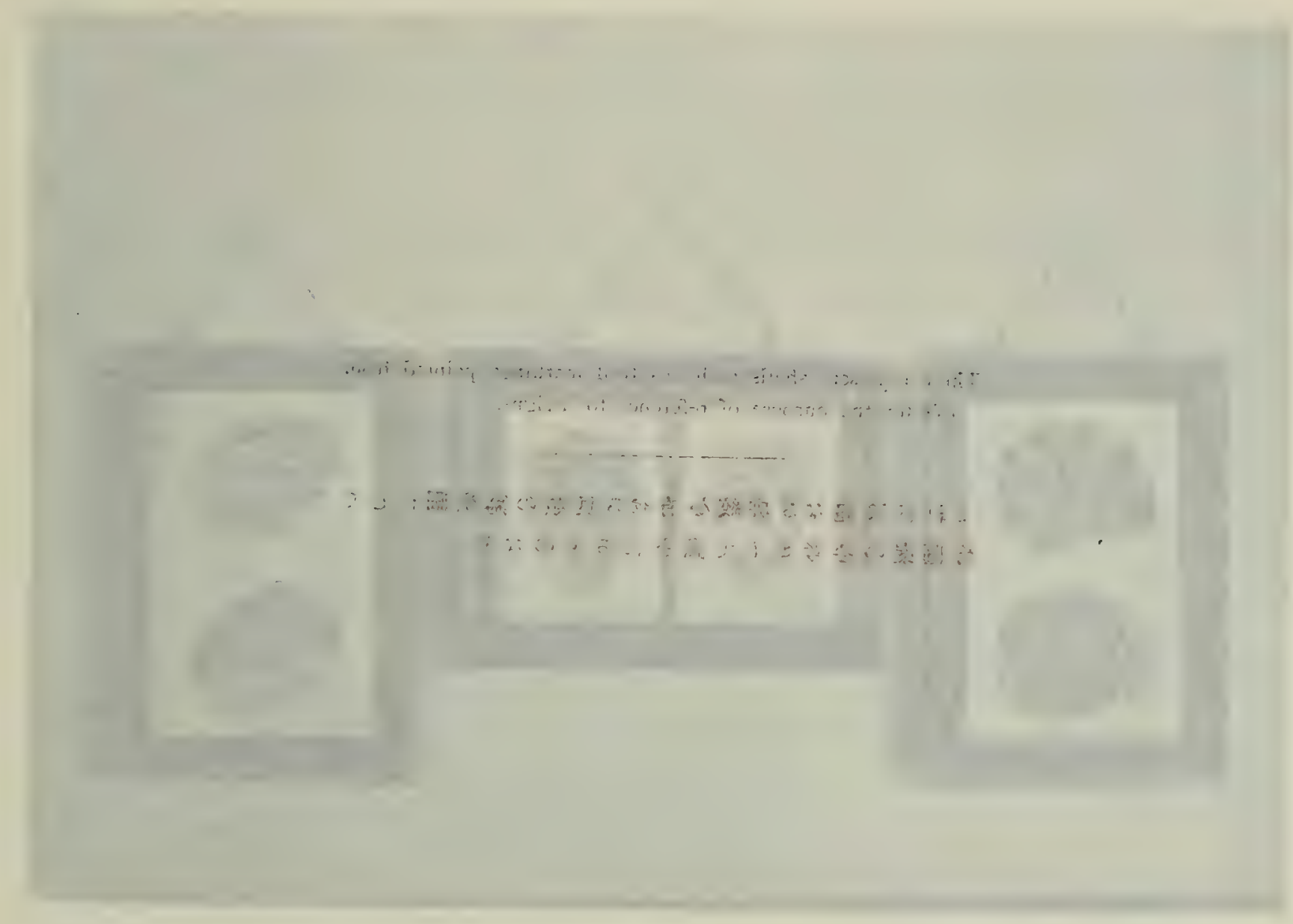


These represent shells with beautiful markings, painted from life for the purpose of reference to designs.

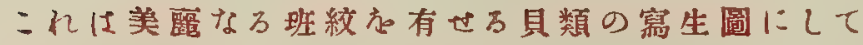

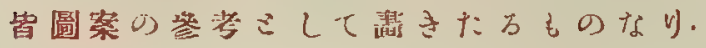




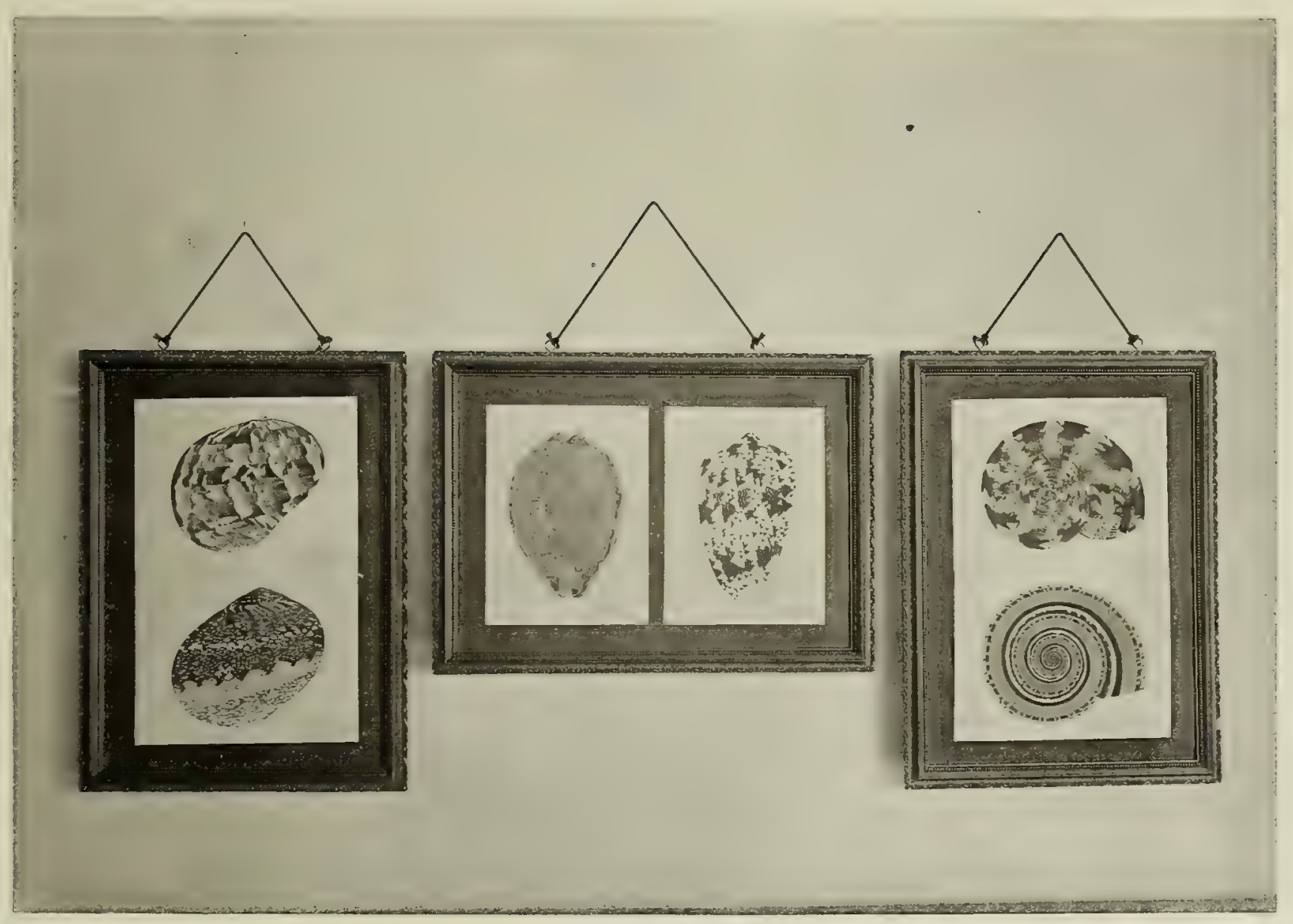




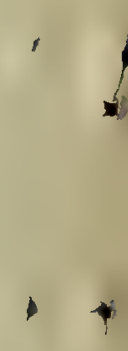
$\psi$

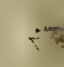

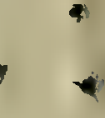




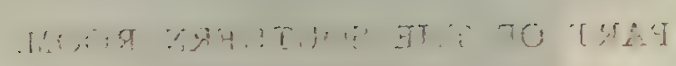

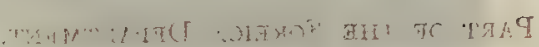

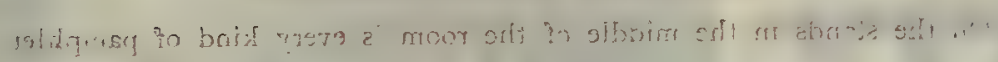
I' it. $\therefore \geq \operatorname{lri}=$

- -.......

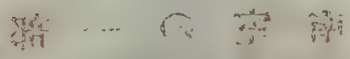

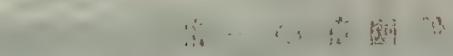

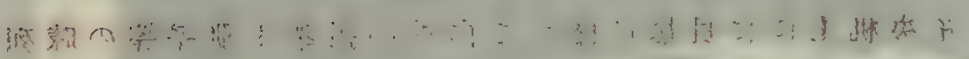


PART OF THE SOUTHERN ROOM.

PART OF THE Foreign DEPARTMENT.

On the stands in the middle of the room is every kind of pamphlet relating to shells.

$$
\text { 南室の一部 }
$$

外國部の一部

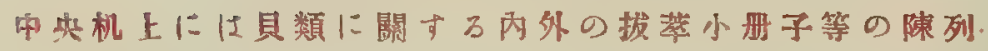




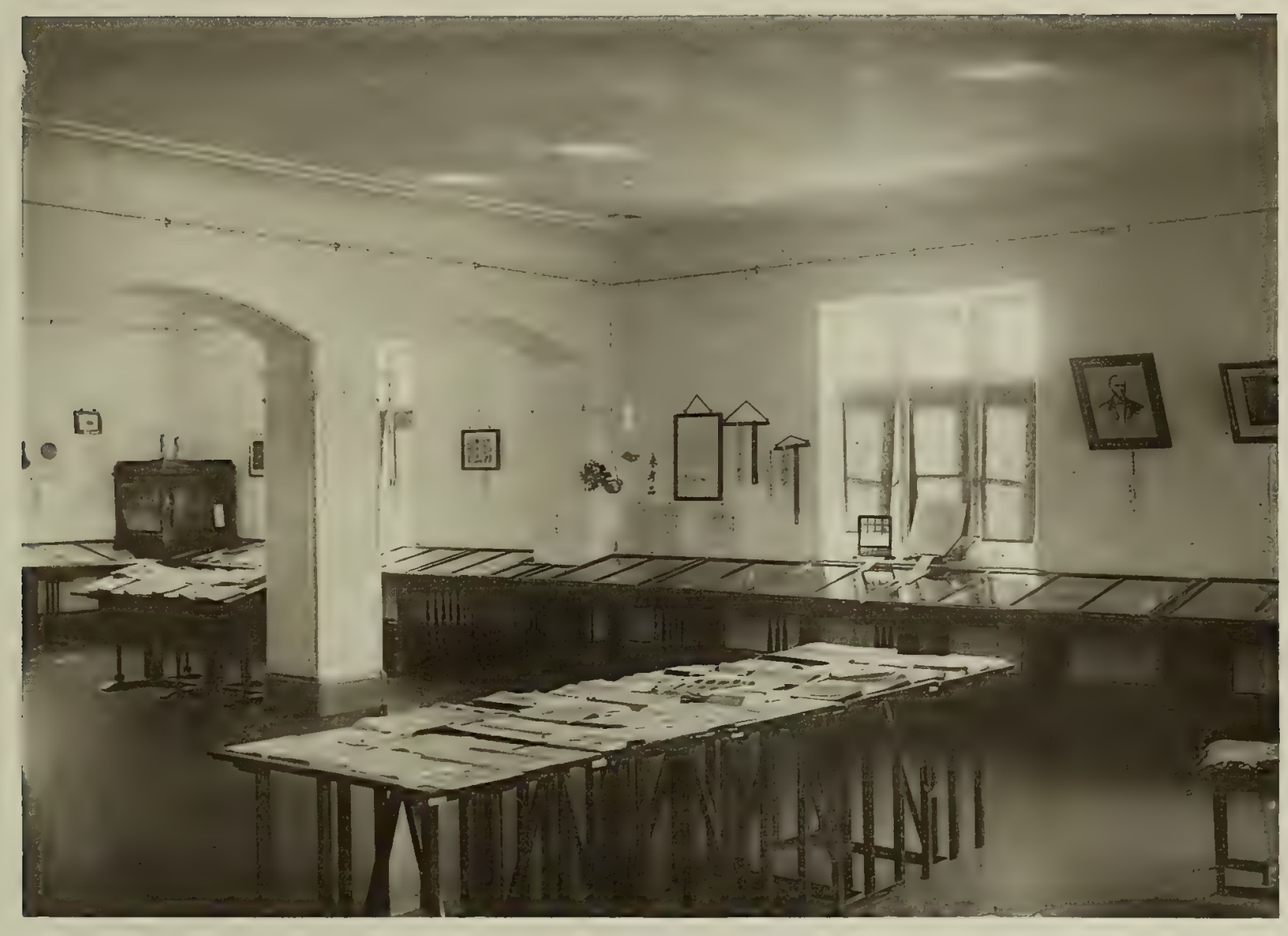




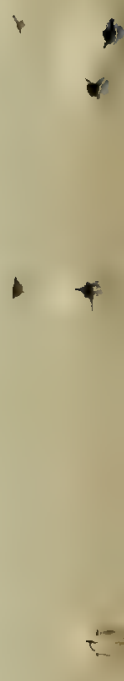

$+$

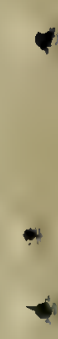





\section{EDIBLE SNAILS.}

The small cabinet on the right is a snailery with 3 species of French snails, kindly presented by Mr. A. Bavay, Paris. The second box contains 12 species of edible snails.

The large shell on the left:--Meleagrina margaritifern.

\section{食 用 螪 牛}

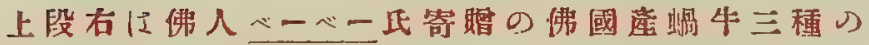
饲養箱. 中の箱仕食用螖牛十二種の標本. 左端任 大形のテフがヒなり。 


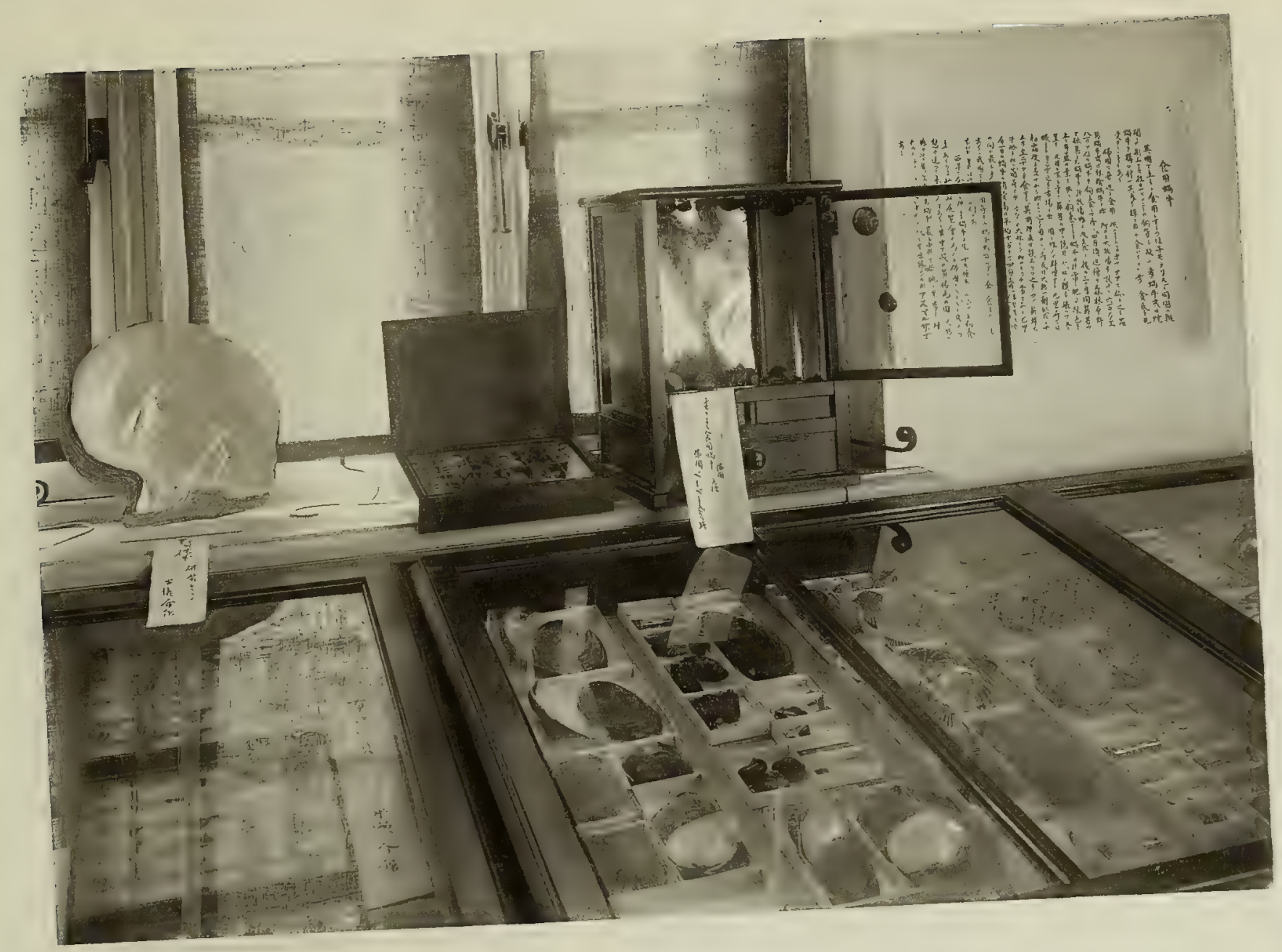


$+$

เ 


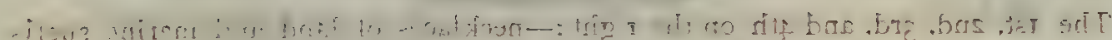

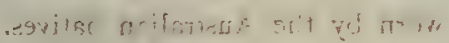

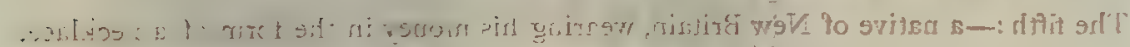

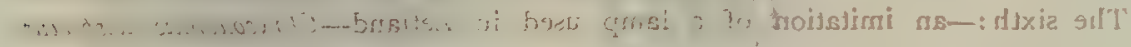

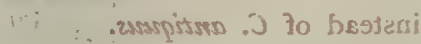

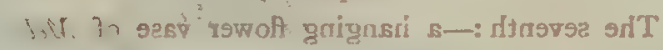

期

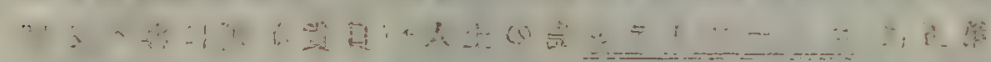

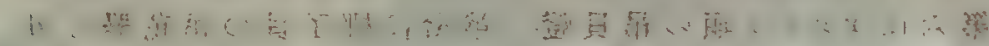




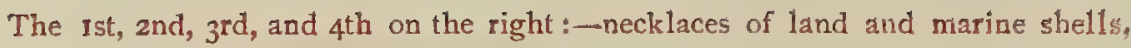
worn by the Australian natives.

The fifth:-a native of New Britain, wearing his money in the form of a necklace. The sixth:-an imitation of a lamp used in Zetland-Chrysodomus despectus instead of $C$. antiquus.

The seventh:--a hanging flower vase of Melo.

向下右より上段第一より第四迄は濠洲土人用陸及海具製首飾。

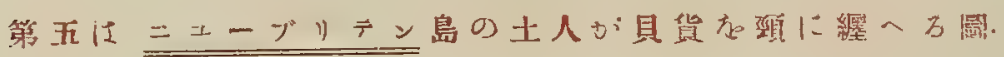

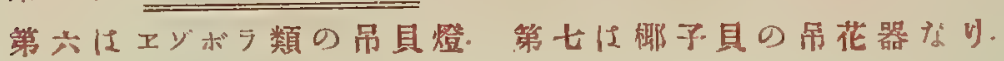




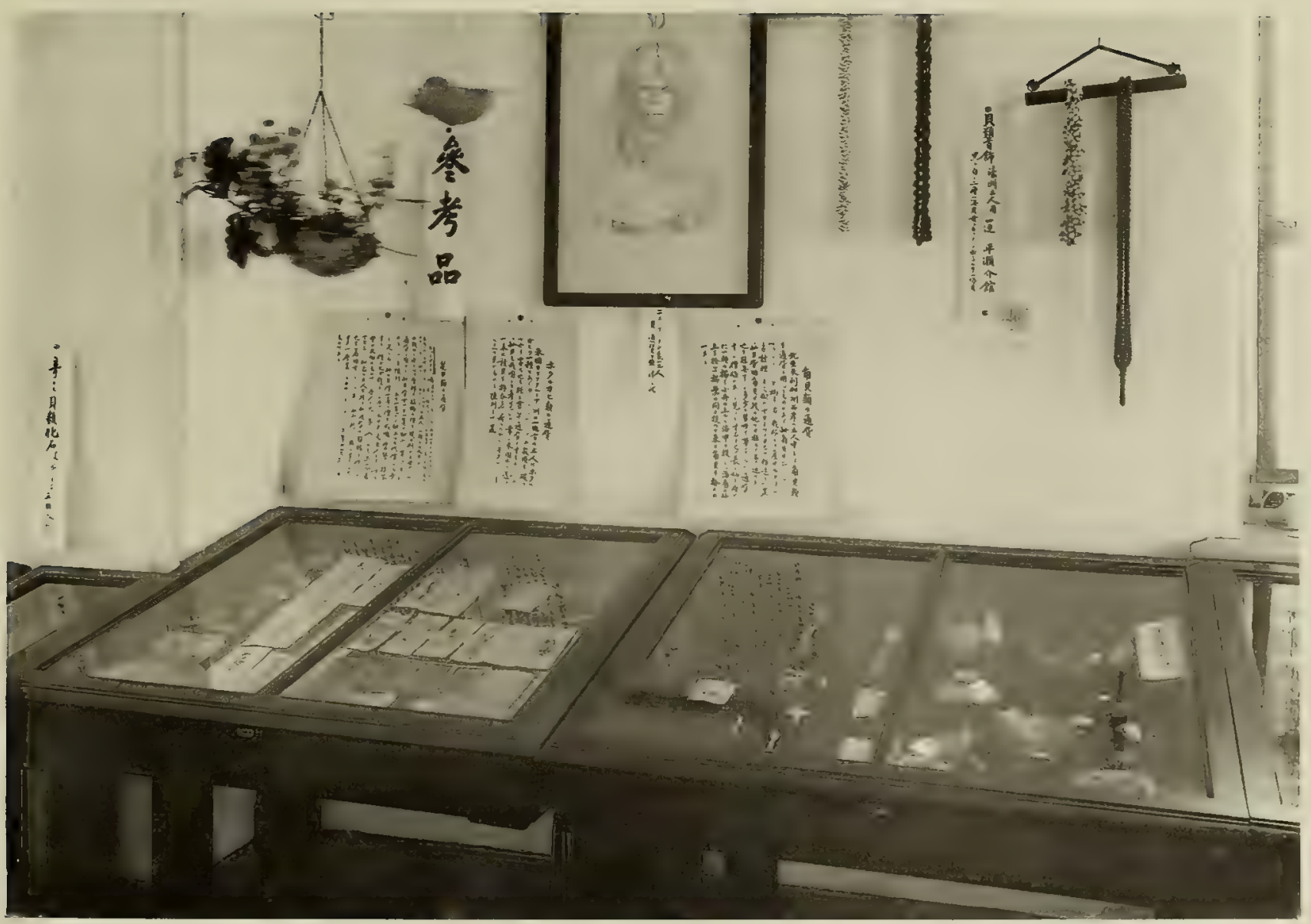


,

4

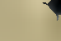




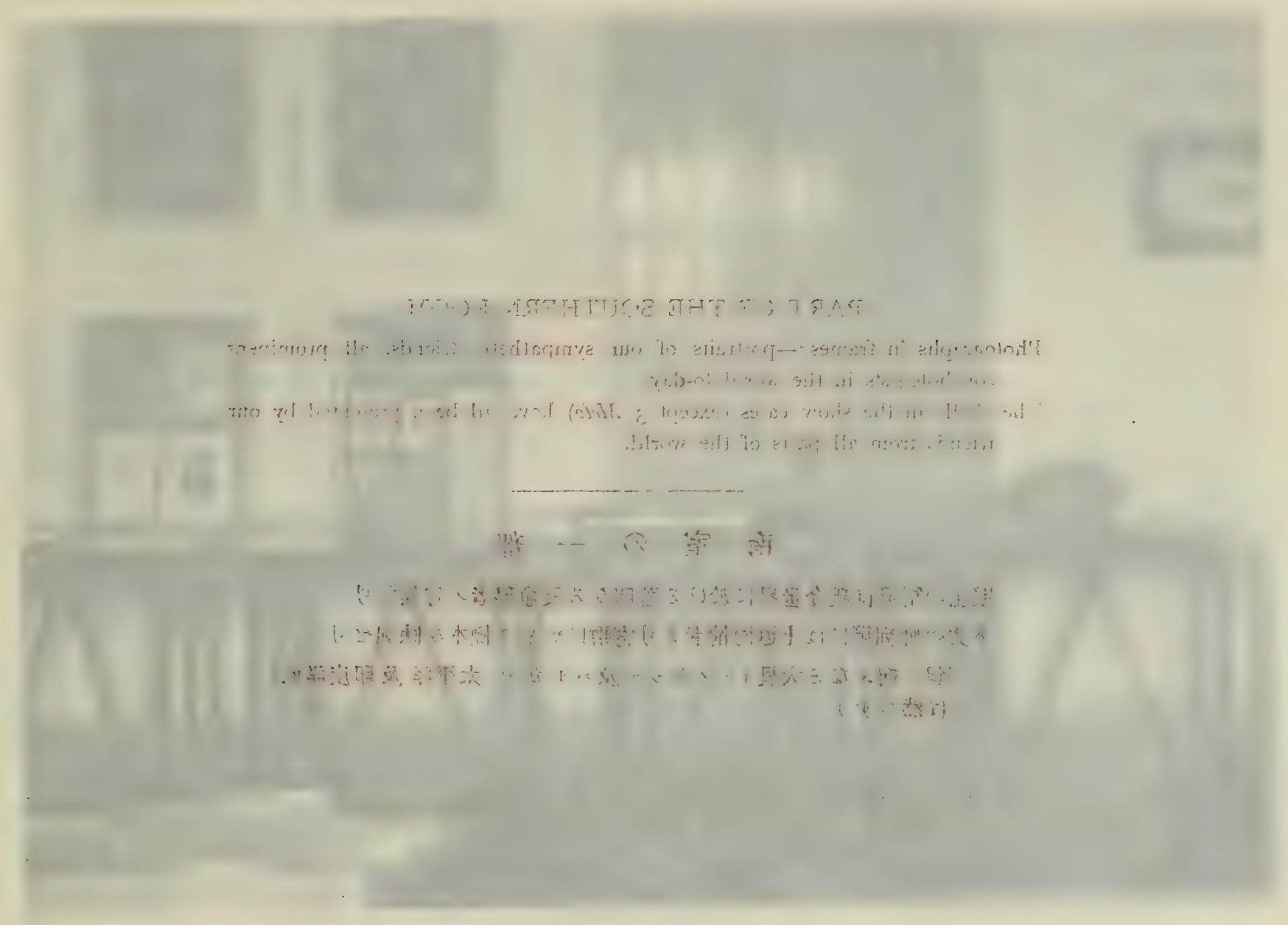


PART OF THE SOUTHERN ROOM.

Photographs in frames:-portraits of our sympathetic friends, all prominent conchologists in the world to-day.

The shells in the show cases (except 3 Melo) have all been presented by our friends from all parts of the world.

\section{南室の一部}

壁上の竄真は現今世界に於ける著明なる具類學著の省像なり。

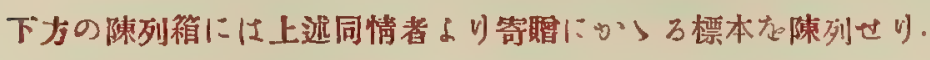

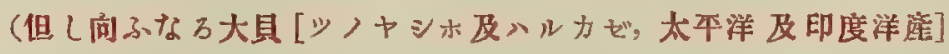
(然らず.) 


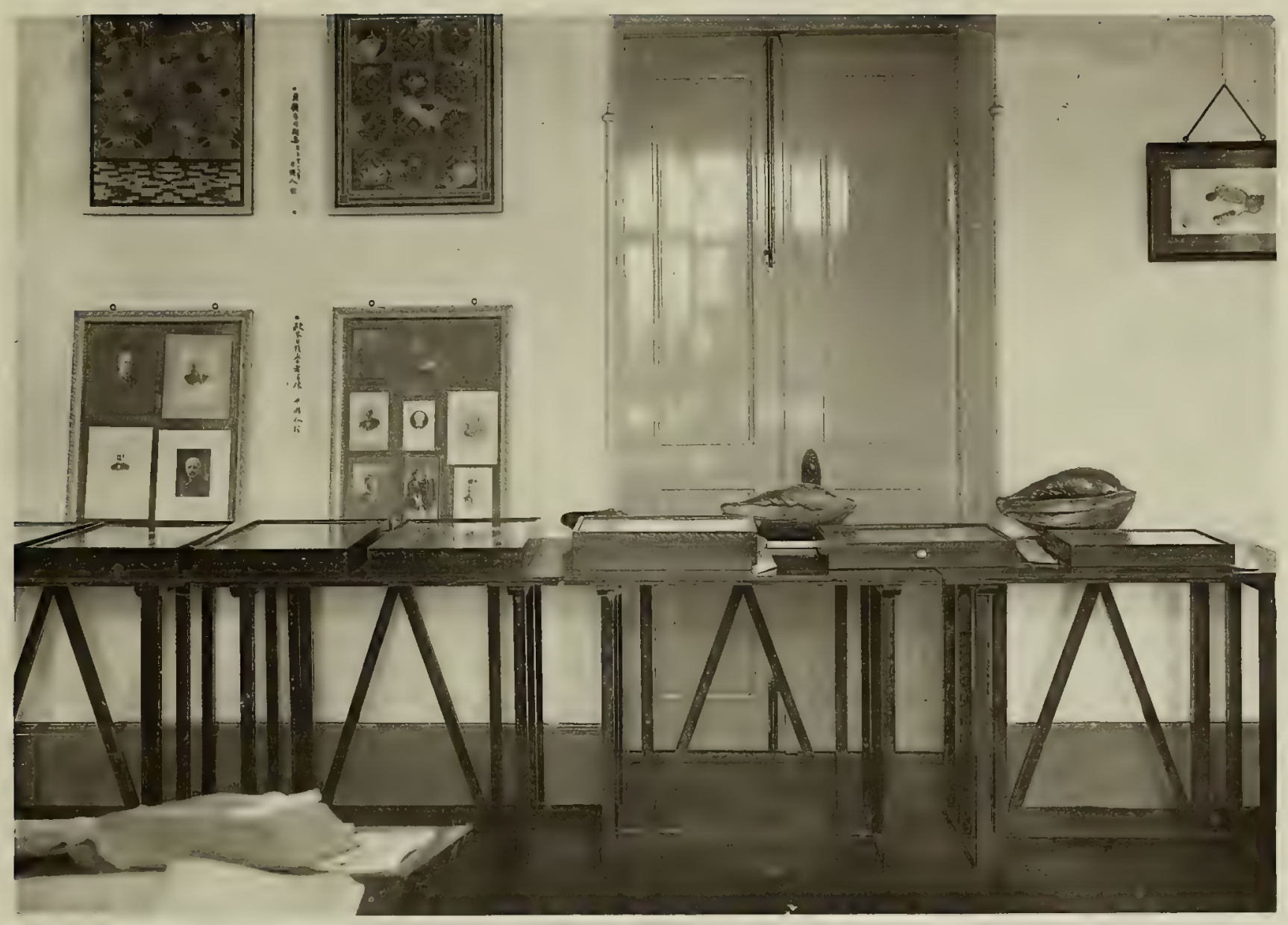


1

$+$ 



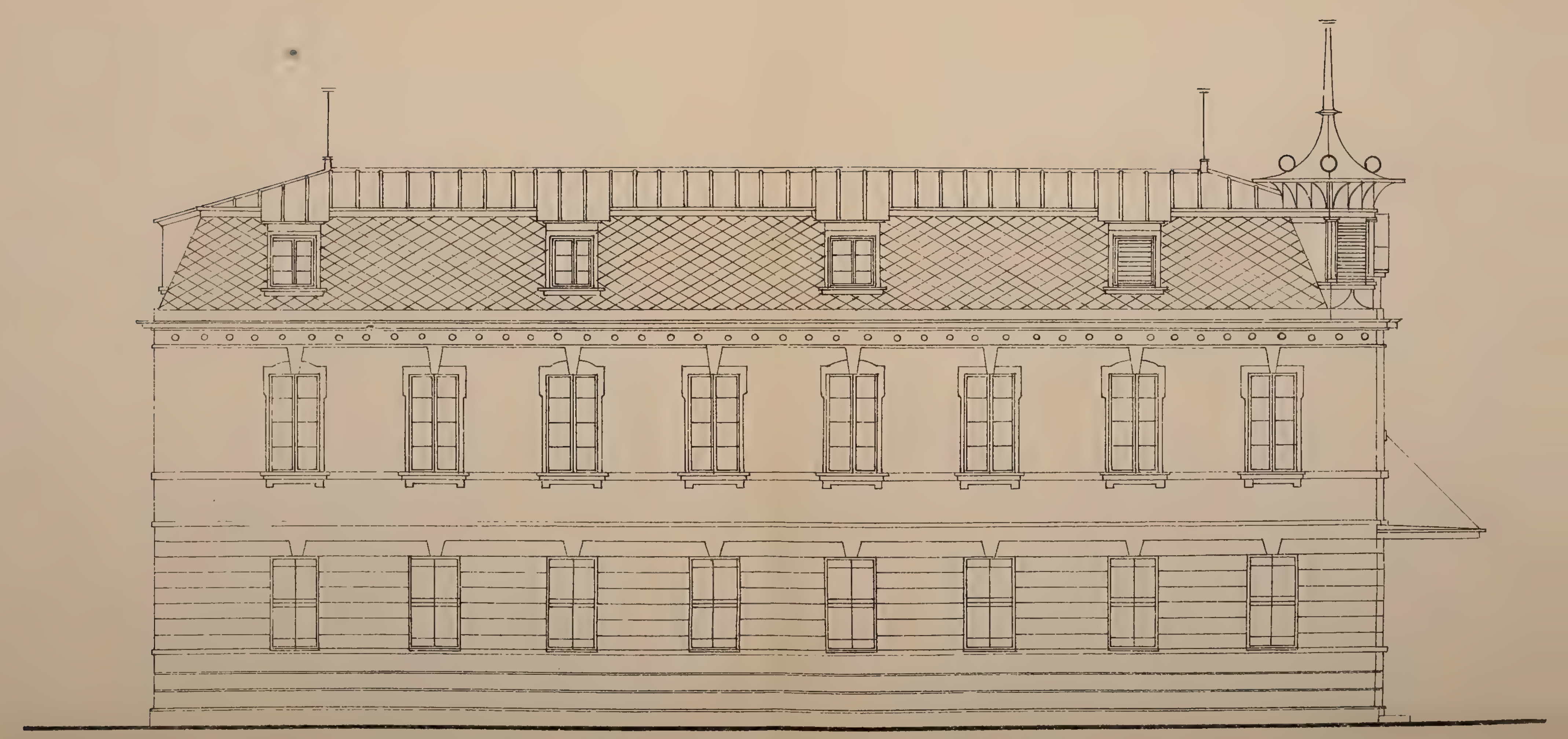




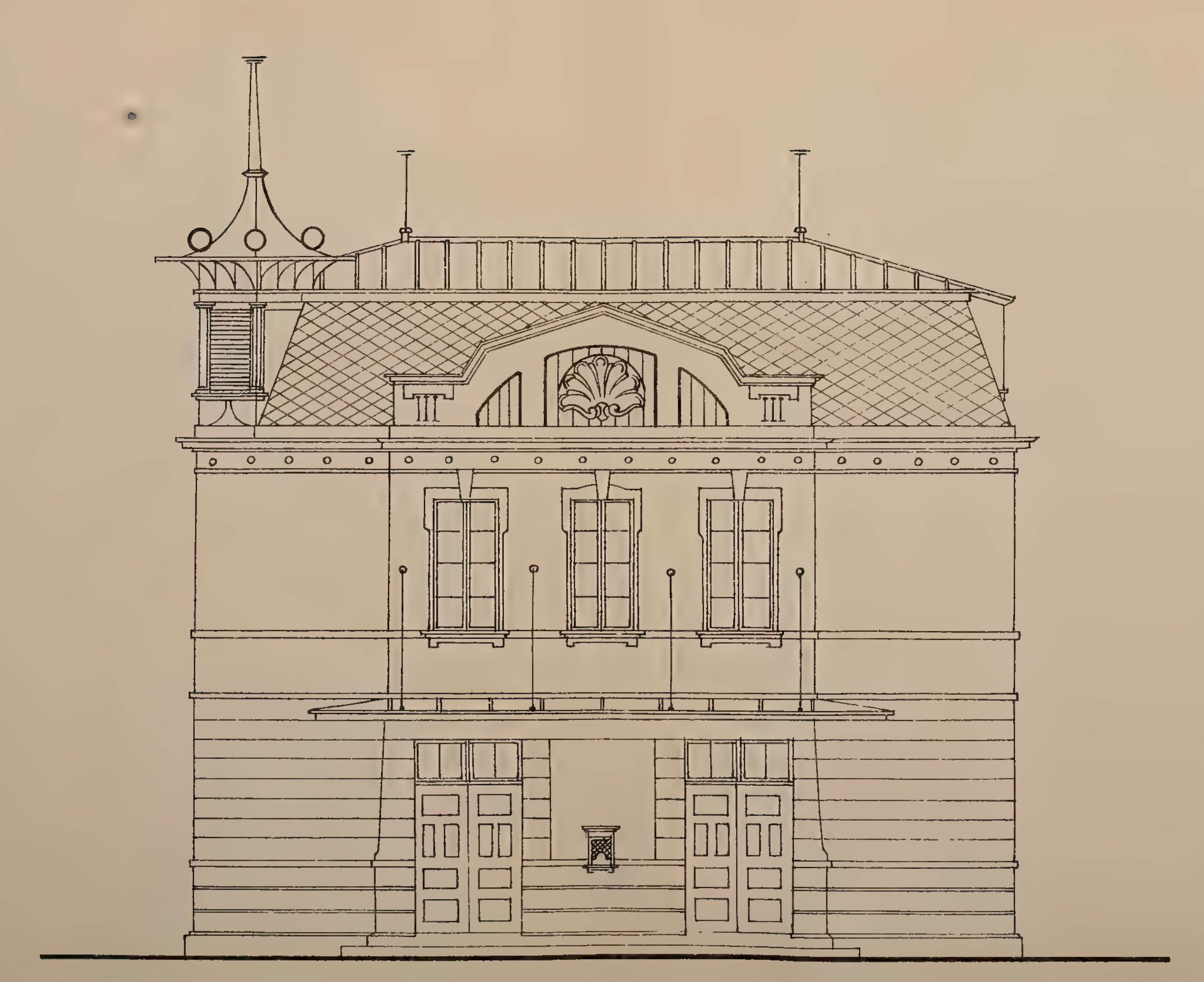




PART OF THE SOUTHERN ROOM.

Picture-Books of Japanese Sheils

南室の一部

和書類陳列 9 - 部 


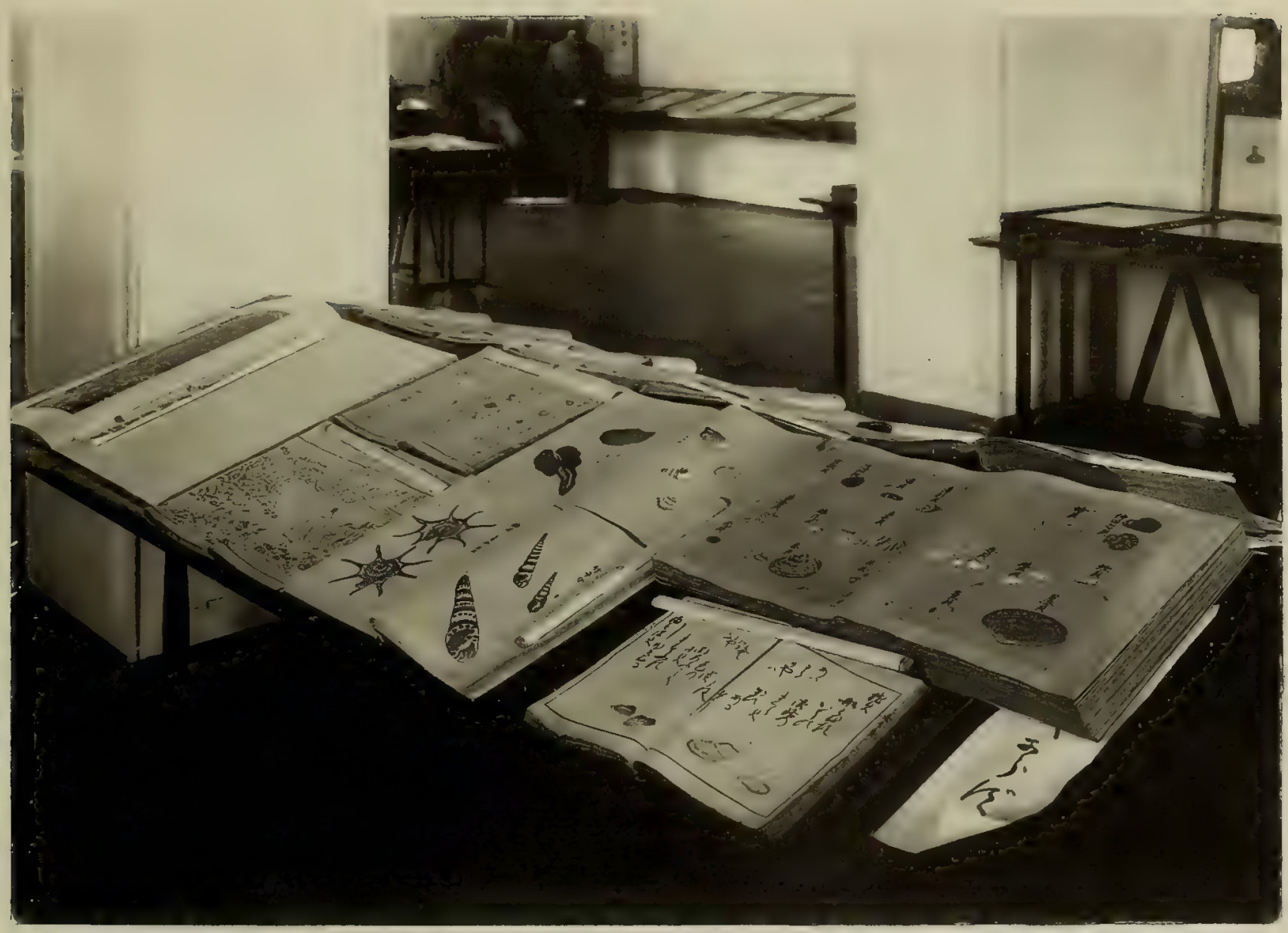




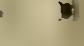


Designs of Unio, Hemicardium, Mitra episcopalis, Tridacna, Scallop, Whelk, Astralium, etc.

シれはシャコ、フデがヒ・カラスがヒ、琉球葵。 板屋具等の罟察なり。 


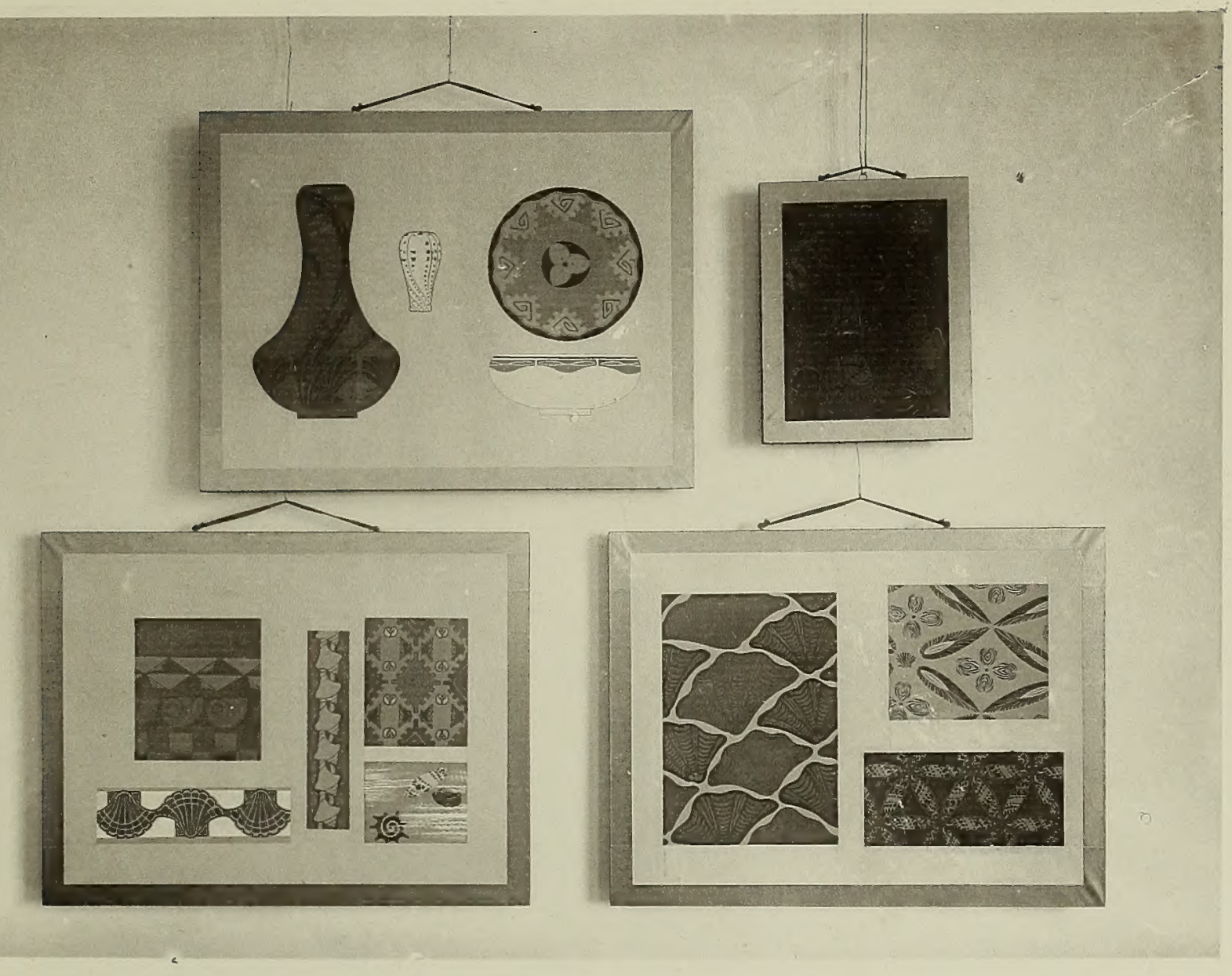


4

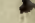


SMITHSONIAN INSTITUTION LIBAARIES 